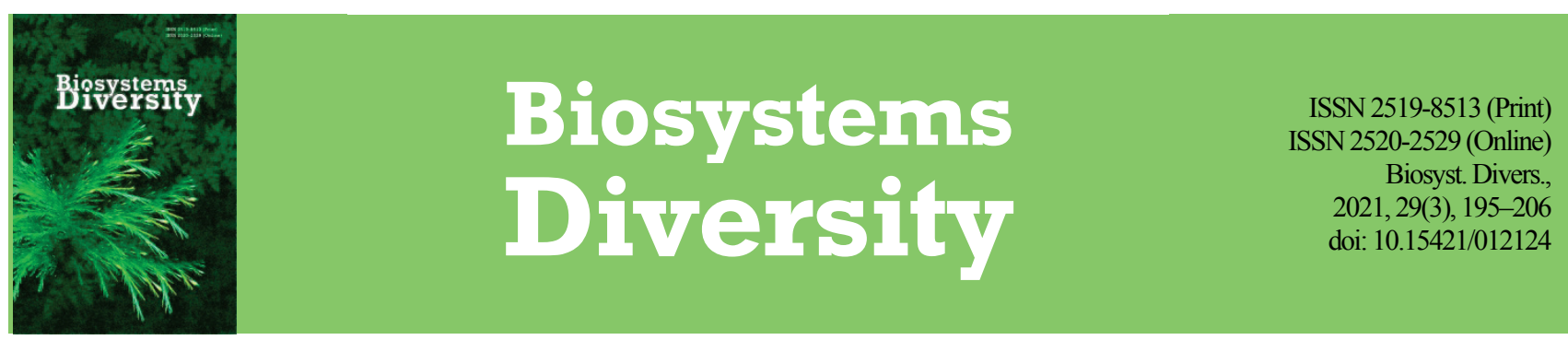

\title{
Phytoindication approach to assessing factors determining the habitat preferences of red deer (Cervus elaphus)
}

\author{
V. I. Domnich*, A. V. Domnich*, O. V. Zhukov** \\ *Zaporizhzhia National University, Zaporizhzhia, Ukraine \\ **Bogdan Khmelnitsky Melitopol State Pedagogical University, Melitopol, Ukraine
}

Article info

Received 08.07.2021

Received in revised form 11.08.2021

Accepted 14.08.2021

Zaporizhzhia National University, Zhukovskyst. 66, Zaporizhzhia,

69600, Ukraine

Tel.: + 38-067-612-66-23.

E-mail:

domvidbio@gmail.com

Bogdan Khmelnitsky Melitopol State

Pedagogical University,

Hetmanska st., 20

Melitopol, 72318, Ukraine

Tel.: +38-098-507-96-82.

E-mail:

zhukovdnipro@ukr.net

\author{
Domnich, V. I., Domnich, A. V., \& Zhukov, O. V. (2021). Phytoindication approach to assessing factors determining the habitat prefe- \\ rences of red deer (Cervus elaphus). Biosystems Diversity, 29(3), 195-206. doi:10.15421/012124
}

The study examined the possibility of using the phytoindication technique to describe habitat preferences of red deer in a relatively homogeneous area. Two alternative hypotheses were tested. Hypothesis 1 suggests that the relationship between red deer and vegetation is due to a trophic factor, so preferences for individual plant species cause vegetation to influence the distribution of animal numbers. Hypothesis 2 suggests that environmental factors influence vegetation, structuring and determining the productive level of the community as a whole. Therefore, environmental factors, rather than individual plant species, cause vegetation-animal interactions. The research was conducted on Biryuchiy Island Spit, where the Azov-Sivash National Nature Park is located. The geobotanical surveys were performed in three types of ecosystems: sandy steppe (vegetation class Festucetea vaginatae), saline meadows (vegetation class Festuco-Puccinellietea), and artificial forest plantation (vegetation class Robinietea). 250 releves were recorded according to the Brown-Blanquet approach. The number of fecal pellets and the number of groups of pellets of red deer was recorded together with geobotanical surveys in the same sample plots. The pellet groups counted in the field were converted to deer densities in specific vegetation classes taking into account the number of pellet groups on the site and the decay rate of the fecal pellets. The vegetation types were distinguished by the number of deer fecal pellets per unit area. The highest number of fecal pellets was found for the plant class Festucetea vaginatae, somewhat fewer fecal pellets were in the plant class Robinietea, and the lowest number was in the plant class Festuco-Puccinellietea. A geometric distribution model is adequate for explaining the experimental data on the number of fecal pellets. A total of 59 species of flowering plants were found. Based on the species composition and projective cover of species, the ecological regimes of ecotopes were identified by phytoindication. The correspondence analysis of the vegetation revealed two ordination axes. The ordination axis 1 (CA1) was able to explain $11.3 \%$ of community inertia, and the ordination axis 2 (CA2) was able to explain 5.2\% of community inertia. The maximum excretory activity of animals was recorded for the central part of the ordination space, indicating the presence of an optimum zone in the gradient of environmental factors that structure plant communities. The forward selection procedure allowed the Nutrients Availability variable to be selected as the most important variable to explain variation in the plant community structure. The number of deer fecal pellets exhibited different patterns of response in the Nutrients Availability gradient. The response within the plant class Festucetea vaginatae could best be explained by Model III from the list of HOF-models. The response of the excretory activity of deer within the class Festuco-Puccinellietea could best be fitted by the model IV, which represents a symmetric Gaussian curve. The response of excretory activity in the Robinietea vegetation class was asymmetrical bimodal. The ecological properties of the red deer ecological niche in both the drier and less mineralized part of the range of ecological conditions and the wetter and more mineralized part should be assessed in the context of the prospects for future studies.

Keywords: Cervidae; ecological niche; nitrogen content in soil; population management; Mantel test; species response.

\section{Introduction}

Ungulates are broadly considered to be the primary herbivores and ecosystem engineers in wetland, grassland, and forest systems worldwide (Waller \& Alverson, 1997; Sabo et al., 2017). Ungulates influence nutrient cycling, net primary production, and disturbance regimes in terrestrial ecosystems (Hobbs, 1996). Ungulate activity affects the structure and function of grasslands, including the physical structure of the environment and the rate of a number of ecosystem-level processes (Knapp et al., 1999). Native and introduced ungulates modify the composition and structure of plant communities through frugivory, grass grazing, and foraging of tree plants and grasses (Bodmer, 1990). Ungulates play a particular role in the spread of ruderal and grassland species in agricultural landscapes. The dispersal by large mammals is an important mechanism for the spread of plants over long distances (Heinken \& Raudnitschka, 2002). Wild ungulates considerably affected successional pathways and species composition in open habitats (Tschöpe et al., 2011).

The red deer (Cervus elaphus Linnaeus, 1758) is one of the most widely distributed free-roaming large herbivorous species in Europe (Mül- ler et al., 2017). As an ecosystem engineer, red deer affects the living conditions of other species through impacts on the vegetation, largely through grazing and trampling (Kuijper et al., 2010). The impact of deer on natural ecosystems is significant. By feeding selectively, deer affect the growth and survival of many species of grasses, shrubs, and trees, altering patterns of relative abundance and vegetation dynamics. Ungulates can profoundly alter the structure and composition of ecosystems through direct and indirect mechanisms. Individual plant species often respond uniquely to direct herbivore pressure depending on their sensitivity to ungulate damage, ungulate food preferences, and density of ungulate presence. Deer herbivory is responsible for the reduced viability, competitiveness, and fecundity of some plant species Sustained pressure from herbivores can restrict plant regeneration. These losses, in turn, lead to indirect consequences through trophic cascades or physical alteration of habitat (Rooney \& Waller, 2003). The cascading effects on other species extend to insects, birds, and other mammals (Côté et al., 2004). Dietary selection by ungulates has a significant impact on plant communities (Hanley, 1997). An increase in deer population density reduced percent cover of nitrophilous herbaceous species and increased percent cover of graminoid grasses (Dufresne et al., 
2009). Plant species that are trophically preferable are not the only ones that can decline under the influence of deer. Species that are not readily consumed by deer decrease in abundance due to the deterioration of soil properties caused by deer. An increase in soil penetration resistance and a decrease in litter thickness negatively affects some unpalatable plant species (Heckel et al., 2010). The recovery of plant community biodiversity after the reduction of the critical level of trophic load by deer can be extremely slow, because the preferred herbivore species have practically disappeared from the ecosystems and cannot recharge the refugia. There is a significant time lag between the reduction in herbivore numbers and the response of the plant community after a long period of high deer population density (Pendergast et al., 2016). The destructive feeding behaviour of animals that lead to disruption of the root system can reduce vegetation cover, diversity, and regeneration (Barrios-Garcia \& Ballari, 2012). The revegetation of species consumed by deer was largely limited to those that were able to persist under conditions of intense herbivory (Webster et al., 2005; Long et al., 2007). Overabundance of deer contributes to the success of invasive plant species dispersal (Knight et al., 2009). The increased deer density causes a significant, profound legacy effect on vegetation that persists for at least 20 years. Reduced deer density alone does not guarantee revegetation (Nuttle et al., 2014). There is a close connection between the diversity and functional status of ecosystems (Sokolov \& Zhukov, 2017; Zhukov et al., 2018; Zymaroieva et al., 2021). The grazing gradients of ungulates, including red deer, can contribute to the conservation and restoration of carabid diversity by creating living conditions for species that are sensitive to different grazing pressures (Melis et al., 2006). Thus, the functional significance of the red deer is very important, and it depends greatly on the type of ecosystem which the animal inhabits.

The species diversity of grassland plant communities depends on grazing, which provides their rich botanical composition. Communities rapidly lose species when grazing declines or terminates (Ball, 1974; Hierl et al., 2008). There is evidence that the botanical value of species-rich grasslands is threatened by deer decline (Britton \& Pakeman, 2009). This threat is unevenly distributed across space. Despite their attractiveness to herbivores, locally isolated areas of grassland that are not grazing hotspots will be the first areas to be negatively affected by further reductions in grazing levels (Moore et al., 2015). Changes in the environment caused by deer can lead to pervasive changes in the demographics of herbaceous plant species. Deer herbivory may influence the trajectory of plant communities and be a mechanism for reducing $\beta$-diversity along ecological gradients (Holmes \& Webster, 2011) A concentration of large ungulates at foraging sites can lead to impulsive spatial subsidization of resources with cascading effects on the vegetation composition and trajectory (Tahtinen et al., 2014). There are observations that deer select plants based on plant abundance rather than specific plant species (Kay \& Staines, 1981). The red deer shows a strong preference for leguminous plants with high nutritional value (Semiadil et al., 1995).

Red deer are biotopically selective, which is influenced by a variety of environmental factors. Habitat selection is driven by forage quantity and quality, with vegetation composition being the most important factor in selecting a particular foraging habitat (Bobrowski et al., 2015). Red deer prefer species-rich grasslands and forest gaps with a high abundance of herbaceous plants or forbs (Kuijper, 2011; Moore et al., 2015). The larger home range size can be considered an adaptation of deer to less energy intake (Massé \& Côté, 2012). Spatial heterogeneity of resources can reduce the effect of negative density-dependent feedback. Therefore, long-term persistence of high densities of large herbivores is possible in a heterogeneous environment (Massé \& Côté, 2012). The early successional stages of vegetation development are characterized by high quality forages preferred by deer (Massé \& Côté, 2012; Bobrowski et al., 2015). Deer may prefer young, dense conifer stands, especially in winter when better forage alternatives are unavailable (Debeljak et al., 2001). Increased deer density leads to greater use of less preferred habitat (Pérez-Barbería et al., 2013). The biotopic selectivity of red deer can be assessed using methods of abundance accounting, which make it possible to estimate this index in certain biotopes. Fecal pellet counting has been used to determine deer numbers in habitats where animals are difficult to count directly since the 1930s (Bennett et al., 1940; Eberhardt \& Etten, 1956; Bagherirad et al., 2013).
The ecological niche theory is an effective generalization for describing the habitat preference of animal species (Hirzel et al., 2002; Hirzel \& Le Lay, 2008; Zimaroeva et al., 2016; Ponomarenko et al., 2021). An important problem is the consideration of environmental parameters that can indicate the ecological niche of animals (Kunakh et al., 2018; Zhukov et al., 2021). Depending on the scale of consideration of spatial patterns, the list of ecological indicators may change (Yorkina et al., 2018). Thus, to describe the habitat preference of red deer within the Iberian Peninsula, three groups of indicators were applied: climatic, geomorphological, habitat structure, and anthropogenic pressure (Acevedo \& Cassinello, 2009). Obviously, the list of ecological predictors of the ecological niche should be quite different for the conditions of Biryuchiy Island. The relief and climatic conditions of the island are practically homogeneous, anthropogenic impact is minimized as a result of the protection regime. In this connection, the application of the phytoindication method to describe the properties of the red deer ecological niche is of interest. In animal ecology, plant indicator scales are rarely used to address ecological questions. Significant relationships have been found between plant indicator scales and the diversity of flies (Williams et al., 2009), butterflies (Oostermeijer \& van Swaay, 1998; Konvicka et al., 2003; Feest et al., 2014; Tiitsaar et al., 2016; Pielech et al., 2017), and mollusks (Horsák et al., 2007; Kappes et al., 2014). These studies emphasize the advantages of using indicator scales in the study of animal autoecology. But this approach is still understudied and requires more detailed consideration.

The objective of the study was to assess the possibility of using the phytoindication technique to describe habitat preferences of red deer in relatively homogeneous terrain. We formulated the following hypotheses. Hypothesis 1 . The connection between deer and vegetation is driven by a trophic factor, so preferences of individual plant species cause vegetation to influence the distribution of animal numbers. Hypothesis 2. Environmental factors influence vegetation cover, structuring and determining the productive level of the community as a whole. The environmental factors, rather than individual plant species, are the cause of the vegetation-animal relationship.

\section{Materials and methods}

The research was conducted on Biryuchiy Island Spit, where the Azov-Sivash National Nature Park is located. The Biryuchy Island Spit is called both a peninsula and an island, because sometimes, when strong easterly winds blow, the Fedotov Spit is washed over in some places. The Spit of Biryuchiy Island is connected with the mainland by the narrow (in some places $100 \mathrm{~m}$ ) Fedotov Spit of alluvial origin. The Spit of Biryuchiy Island has a length of $25 \mathrm{~km}$, its width reaches from 3 to $5 \mathrm{~km}$ (Mirzoeva \& Zhukov, 2021). The southern shore of the spit is flat, sandy, the northern one has numerous small bays. The higher southeastern shore of Biryuchiy Island is surrounded by the waters of the Azov Sea. A sandy bank rises from 1.5 to $5.0 \mathrm{~m}$ high. The north-western shore is bounded by the Utlyuk Estuary. This seashore is low, passes into shallow water with reed beds. Here, flat sandy-shell ridges with lush and diverse steppe vegetation alternate with solonchak hollows bordered by reedbeds. On the territory of Azov-Sivashsky National Nature Park a system of small bays, about $112 \mathrm{~km}$ long, is formed, which are dissected by small peninsulas, spits, throughout the bays there are scattered large, small and very small islands. On the whole, it is a huge labyrinth of shallow and semi-desert landscapes. The hydrological regime of the region is greatly influenced by long and strong tidal winds, which free the bottoms of shallow estuaries and bays from water for hundreds of meters, forming the so-called droughts. Underground waters of the protected islands belong to the Black Sea artesian basin, located between the Ukrainian crystalline shield and the folded system of the Crimean Mountains. Water-bearing horizons are observed at different levels - from 1 to $500 \mathrm{~m}$. The main role in water supply in this area belongs to the Neogene horizons, where groundwater is mostly slightly saline and located at depths of 0.5 to $2.0 \mathrm{~m}$. On Biryuchiy Island Spit, in its southernmost part, groundwater occurs at a depth of 1.0 $1.6 \mathrm{~m}$, and at the same time it is fresh, while in its central part - at a depth of $0.8-1.3 \mathrm{~m}$. In the area of protected islands, the Sea of Azov sometimes freezes (Domnich, 2015). 
The territory has a moderately continental climate with hot long summers and short mild winters. Eastern cyclones prevail in winter. In summer, weather conditions are determined by a high pressure area over Southern Europe. Continental northern air, brought by northeasterly winds, penetrates during the cold season. Western and southwestern winds blow more often in summer. The average wind speed is from 4 to $6.8 \mathrm{~m} / \mathrm{s}$, but in winter stormy northeasterly and easterly winds are possible. The Utlyuk Estuary is covered with ice during the winter months. High summer air temperatures usually lead to drought. The average temperature in July is $23-25^{\circ} \mathrm{C}$, reaching a maximum of $38-40^{\circ} \mathrm{C}$. Winter is relatively short. In January, the average temperature rarely falls below $-4^{\circ} \mathrm{C}$, but there is shallow snow and very severe frosts occur to $-24^{\circ} \mathrm{C}$. The frostfree period lasts $180-200$ days. The vegetation period is $130-250$ days. The annual amount of precipitation reaches $300-315 \mathrm{~mm}$, of which 100 to $260 \mathrm{~mm}$ falls during the warm period. The influence of the Black and Azov Seas leads to a softening of frosts and a decrease in the height of snow cover, which usually reaches $5-10 \mathrm{~cm}$. It lasts for 30 to 40 days. In some years, the ice cover lasts 4-5 months, from December till April. The ice thickness can reach $90 \mathrm{~cm}$. In summer, the waters of the Azov Sea are well heated and illuminated, creating favourable conditions for the development of flora and fauna. The maximum temperature of the surface layer sometimes exceeds $30^{\circ} \mathrm{C}$ near the shores and in the central part of the sea $28^{\circ} \mathrm{C}$ (Domnich, 2015).

On islands of the reserve soils are formed under relatively low relative humidity under the influence of tidal currents. On the island of Biryuchiy the pure sands occupy coastal strips along the Azov Sea (30-100 m) and large estuaries $(10-20 \mathrm{~m})$, there is no vegetation here. Only solitary psammophilous plants are found on unstabilized sands. Stabilized sands are covered with vegetation of sand dune classes Honckenyo-Elymetea arenarii, less often Festucetea vaginatae (Dubyna et al., 1994). The primitive sandy-pebbly sand-steppe and solonchak soils are chestnut-coloured and have varying content of organic matter, sand or sea shells, and with varying salinity. Moderately organic-rich solonchak soils are very common in this group. At a depth of about $50-80 \mathrm{~cm}$, a layer of shell fragments cemented by sand is formed, on which sedimentary water accumulates. Meadow soils are found in areas with fresh groundwater, occurring at a depth of about $0.5-0.8 \mathrm{~m}$. These soils are of chestnut colour, have admixture of shell rock and with different percentage of sand or loam and with different intensity of salinization. Solonchak soils of various textures fill landscape depressions with marsh (Phragmites australis) and halophilic vegetation (Juncus gerardii). Groundwater contains $30-50 \mathrm{~g} / \mathrm{L}$ salt. Nonsaline marsh-meadow soils with predominance of $P h$. australis are also found in limited areas. Swamp solonchaks occur on the island (Dubyna et al., 1995).

The total area of Biryuchy Island is 7,200 hectares. The geobotanical surveys were performed in three types of ecosystems: sandy steppe (vegetation class Festucetea vaginatae), saline meadows (vegetation class Festuco-Puccinellietea), and artificial forest plantation (vegetation class Robinietea). Sandy steppe occupies 2,050 hectares, saline meadows occupy 1,950 hectares, and artificial forest plantation occupies 232 hectares (Kolomiychuk \& Bezkorovajnyj, 2011). 250 releves were recorded according to the Braun-Blanquet (1964) approach. The plant taxa were identified mainly according to Identification key to higher plants of Ukraine (Dobrochaeva et al., 1987). Species dominance, originally expressed as a percentage for more detailed studies, was converted to the Brown-Blanquet scale. Vegetation was recorded on an area of $9 \mathrm{~m}^{2}(3 \times 3 \mathrm{~m})$. The description of the grass cover alone performed. A phytoindication of environmental factors was performed based on the Didukh (2011) and Ellenbergtype indicator values (Ellenberg, 1991; Chytry et al., 2018). Didukh indicator values include characteristics of edaphotope and climatope. The edaphotope is characterized by indicators such as the soil water regime $(\mathrm{Hd})$, the variability of damping $(\mathrm{fH})$, the soil aeration $(\mathrm{Ae})$, the soil acidity $(\mathrm{Rc})$, the total salt regime $(\mathrm{Sl})$, the carbonate content in soil $(\mathrm{Ca}), 6$ the nitrogen content in soil (Nt). The climatope is characterized by indicators such as the radiation balance (thermal climate, Tm), the aridity or humidity (ombroregime, $\mathrm{Om}$ ), the continentality (continental climate, $\mathrm{Kn}$ ), the rigours of the winter (cryo-climate, $\mathrm{Cr}$ ), the light regime (Lc). Didukh indicator scales are range scales and are represented by two numbers that indicate the lower and upper limit of the range of conditions in which the plant can live (Didukh, 2011). Ellenberg-type indicator values include the light, temperature, moisture, soil reaction, nutrient indicator values. Ellenberg-type indicator values indicate optimum conditions of living for a given species. Numerical Ellenberg-type indicator values were rescaled to the range corresponding to similar Didukh scales. Thus, the Didukh scales indicate the marginal points of the plant ecological niche and the Ellenberg scales indicate the optimal values. The phytoindication assessment with the Didukh scales was performed using the ideal indicator method. Phytoindicator evaluation of environmental factors using Ellenberg scales was performed using the weighted average method. The indicator scales were weighted by the projective covers of plants.

The number of fecal pellets and the number of groups of pellets of red deer was recorded together with geobotanical surveys in the same sample plots. When searching for pellets, we pushed aside growing vegetation and dead branches, but did not disturb the litter layer. We only counted pellets from deer. No sampling was done if we thought it was too dark to detect pellets.

The pellet groups counted in the field were converted to deer densities in specific vegetation classes (Eberhardt \& Etten, 1956):

$$
D_{i}=\frac{10^{6} \times n_{i}}{9 \times t_{i} \times d^{\prime}}
$$

where $D_{i}$ is deer density in the site $i$, individuals per $\mathrm{km}^{2}, \mathrm{n}_{\mathrm{i}}$ is the number of pellet groups in the site $i$; $t_{i}$ is the decay rate for the specific vegetation classes and $d$ is the defecation rate. Considering the impossibility of assessing the defecation rate for this particular population, we assumed a value of 25 pellet groups per day (Mitchell \& McCowan, 1984). The pellet decay rate was estimated based on our earlier data (Domnich, 2015). For steppe ecosystems, this estimate was 1,371 days; for meadow ecosystems, this estimate was 1,026 days; for an artificial forest plantation, this estimate was 1,200 days. Decay rate estimates are 581 days (Alves et al., 2013). In one extreme case, samples taken in July completely disappeared within 95 days. In November, it took about 450 days for complete decay (Mitchell \& McCowan, 1984).

The descriptive statistics were estimated using the software program Statistica (Statsoft). Plant projective cover data were subjected to the arcsine transformation (also called the square root of the arcsine transformation or the angular transformation) (Sokal \& Rohlf, 1995). A preliminary detrended analysis of the community matrix correspondences showed that the length of the first ordinal axis exceeds 2 . On this basis, a correspondence analysis was chosen for the further ordination procedure. The fitting of phytoindication factors into the ordination solution was done with the function envfit from the package vegan. Canonical Correspondence Analysis was performed with phytoindicator factor as explanatory variable (Ter Braak, 1986). The Mantel test was calculated by means of ecodist package (Goslee \& Urban, 2007). Huisman-Olff-Fresco (HOF) models were used to explain the responses of species to environmental gradients (Huisman et al., 1993). This list of models was extended to include seven ecological models (Jansen \& Oksanen, 2013). The Huisman-Olff-Fresco models were computed using the statistical program $\mathrm{R}$ with the package "eHOF" (version 1.9) (Jansen \& Oksanen, 2013).

\section{Results}

The vegetation types were distinguished by the number of deer fecal pellets per unit area (Kruskal-Wallis test $8.91, \mathrm{P}=0.012$ ). The highest number of fecal pellets was found for the plant class Festucetea vaginatae $\left(4.61 \pm 0.50\right.$ per $\left.9 \mathrm{~m}^{2}\right)$, somewhat fewer fecal pellets were in the plant class Robinietea $\left(3.88 \pm 0.59\right.$ per $\left.9 \mathrm{~m}^{2}\right)$, and the lowest number was in the plant class Festuco-Puccinellietea ( $3.02 \pm 0.39$ per $9 \mathrm{~m}^{2}$, Table 1$)$.

A geometric distribution model is adequate for explaining the experimental data on the number of fecal pellets (Fig. 1). Accounting for the number of fecal pellets, the intensity of deer defecation, and the rate of fecal decomposition allows us to estimate the population density of red deer depending on the vegetation class. The resulting estimates indicate that red deer population densities were statistically significantly different between vegetation classes $(\mathrm{F}=3.6, \mathrm{P}<0.001)$. In turn, differences between Festuco-Puccinellietea and Robinietea were not statistically significant (Planned comparison $\mathrm{F}=1.2, \mathrm{P}=0.27$ ). The estimate indicates that the red deer population density in the Festucetea vaginatae vegetation class 
was $18.37 \pm 2.01$ ind. $/ \mathrm{km}^{2}$, in the Festuco-Puccinellietea vegetation class was $11.10 \pm 1.46 \mathrm{ind} / \mathrm{km}^{2}$, in the Robinietea vegetation class was $14.37 \pm$ 2.18 ind. $/ \mathrm{km}^{2}$ (Fig. 2).

\section{Table 1}

The quantity of red deer fecal pellets in the classes of vegetation, vegetation characteristic and species diversity $(x \pm S E)$

\begin{tabular}{lccc}
\hline \multirow{2}{*}{\multicolumn{1}{c}{ Parameters }} & \multicolumn{3}{c}{ Vegetation classes } \\
\cline { 2 - 4 } & $\begin{array}{c}\text { Festucetea } \\
\text { vaginatae } \\
(\mathrm{n}=100)\end{array}$ & $\begin{array}{c}\text { Festuco- } \\
\text { Puccinellietea } \\
(\mathrm{n}=100)\end{array}$ & $\begin{array}{c}\text { Robinietea } \\
(\mathrm{n}=50)\end{array}$ \\
\hline Fecal pellets, number per 9 $\mathrm{m}^{2}$ & $4.61 \pm 0.50$ & $3.02 \pm 0.39$ & $3.88 \pm 0.59$ \\
Grass cover, $\%$ & $54.22 \pm 1.23$ & $87.54 \pm 0.82$ & $78.40 \pm 1.39$ \\
Litter thickness, cm & $0.02 \pm 0.01$ & $0.87 \pm 0.07$ & $0.99 \pm 0.12$ \\
Species number $(\gamma$-diversity) & 43 & 53 & 38 \\
Species number per 9 $\mathrm{m}^{2}(\alpha$-diversity) & $7.10 \pm 0.16$ & $10.07 \pm 0.30$ & $8.18 \pm 0.23$ \\
$\beta$-diversity & 5.01 & 4.26 & 3.65 \\
\hline
\end{tabular}

The projective vegetation covers were statistically significantly different between vegetation classes (for arcsine-transformed data $\mathrm{F}=271.1$, $\mathrm{P}<0.001)$. The highest projective covers were found for the Festuco-Puccinellietea vegetation class $(87.5 \pm 0.8 \%)$, slightly lower projective covers were for the class Robinietea $(78.4 \pm 1.4 \%)$ and significantly lower projective covers were for Festucetea vaginatae $(54.2 \pm 1.2 \%)$. The response of fecal number to projective covers was a bell-shaped curve. The weighted mean of the projective covers with the number of fecal pellets as the weighting variable indicates the optimal value of projective cover in the class Festucetea vaginatae $52.2 \pm 0.5 \%$. Optimal projective cover in the Festuco-Puccinellietea class was $83.7 \pm 0.4 \%$, and in Robinietea this value was $77.1 \pm 0.6 \%$. Thus, in all vegetation classes, the greatest amount of fecal matter was found in conditions with less projective vegetation cover than was typical for the area inhabited by this vegetation class.

Litter in plant communities in the class Festucetea vaginatae was present only in $8 \%$ of cases, whereas in the class Festuco-Puccinellietea litter was present in $99 \%$ of cases, and in the class Robinietea litter was present in $96 \%$ of cases. There was a negative correlation $(\mathrm{r}=-0.21, \mathrm{P}<0.001)$ between the number of fecal pellets and litter thickness. Due to the almost complete absence of litter in the class Festucetea vaginatae, no such correlation was determined. For the class Festuco-Puccinellietea the correlation was $\mathrm{r}=-0.19, \mathrm{P}<0.001$, and for the class Robinietea the correlation was $\mathrm{r}=-0.38, \mathrm{P}<0.001$.
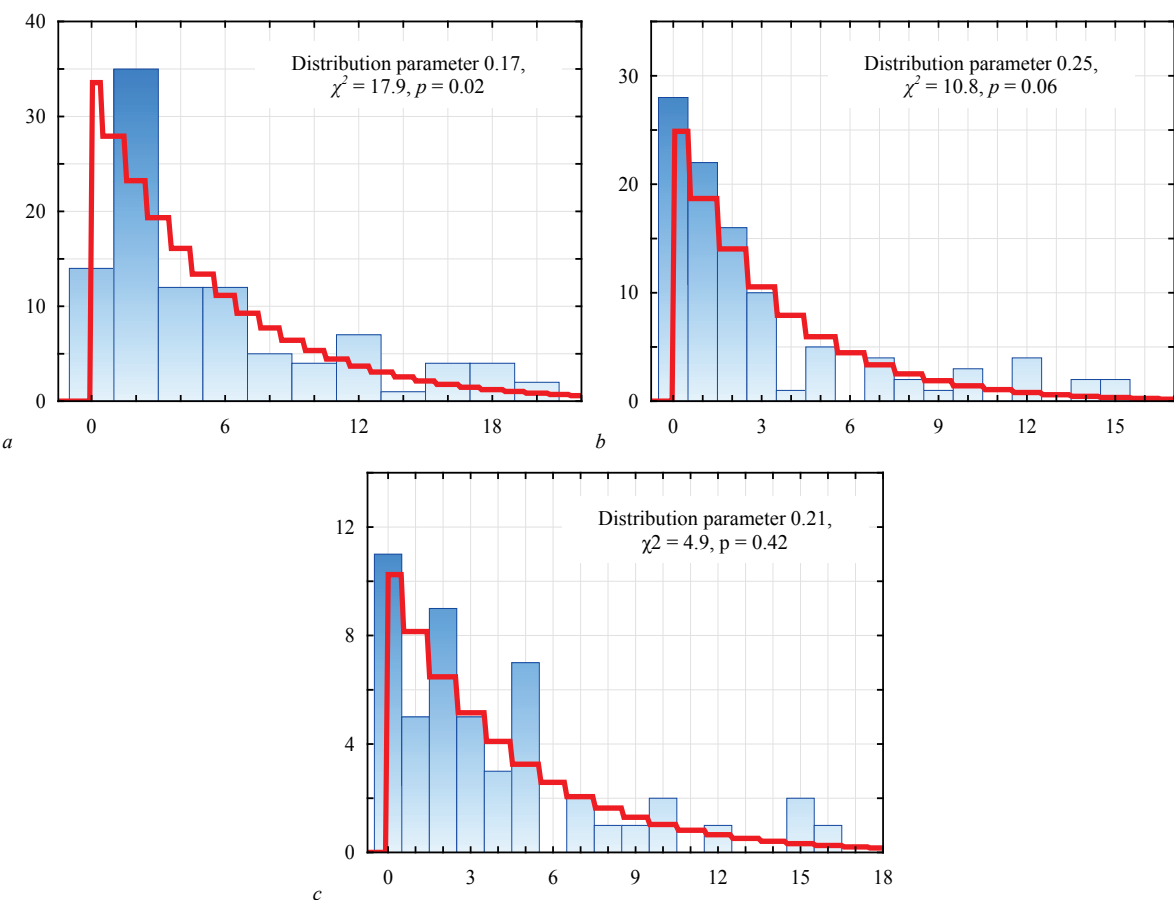

Fig. 1. Distribution of ungulate fecal pellets in the different vegetation classes: $a$-Festucetea vaginatae, $b$-Festuco-Puccinellietea, $c$-Robinietea; abscissa axis is the number of fecal pellets per sampling area, ordinate axis is the number of observations

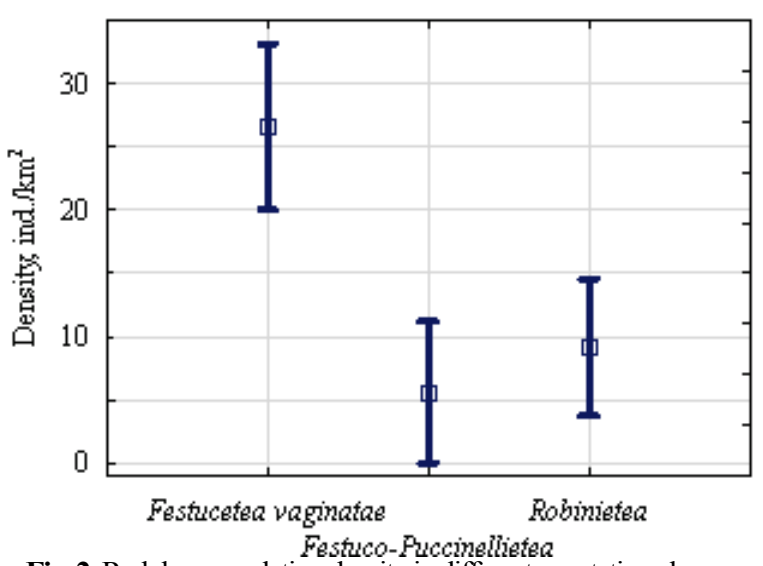

Fig. 2. Red deer population density in different vegetation classes $(\mathrm{F}=4.4, \mathrm{P}=0.01)$ : the abscissa axis is vegetation classes, the ordinate axis is population density; dots are mean value, "whiskers" are $95 \%$ confidence interval
A total of 59 species of flowering plants were found. The class Festucetea vaginatae represented 43 species, the class Festuco-Puccinellietea represented 53 species, and the class Robinietea represented 38 species (Table 2). The number of red deer fecal pellets among the class Festucetea vaginatae was positively correlated with the projective cover of eight plant species: A. dasyanthum, A. maritima, A. santonica, B. japonicas, $C$. acutum, D. muralis, G. aparine, L. meyeri (Table 3).

The correlation with the projective cover of the three species was negative: E. seguieriana, S. sylvestre, T. polium. There was a positive correlation, within the Festuco-Puccinellietea class, between the number of fecal pellets of red deer and the projective cover of the four plant species: A. euxina, C. odessana, C. dactylon, M. peregrinum. The number of red deer fecal pellets among the class Robinietea was positively correlated with the projective cover of five plant species: A. hirsutum, A. setulosa, E. repens, $M$. falcata, $V$. pinnatifidum. The correlation with the projective cover of the $E$. diffusum was negative.

Based on the species composition and projective cover of species, the ecological regimes of ecotopes were identified by phytoindication (Table 4). 
Table 2

Plant communities species diversity and results of the community ordination

\begin{tabular}{|c|c|c|c|c|c|c|}
\hline \multirow[b]{3}{*}{ Species } & \multirow{2}{*}{\multicolumn{3}{|c|}{ Vegetation classes, projective cover, $\%$ mean \pm st.error }} & \multicolumn{3}{|c|}{ Ordination axes scores } \\
\hline & & & & \multirow{2}{*}{$\begin{array}{c}\text { CA } 1 \\
\text { Eigenvalue }=0.53 \text {, } \\
\text { Inertia proportion } \\
\text { explained }=0.11\end{array}$} & \multirow{2}{*}{$\begin{array}{c}\text { CA2 } \\
\text { Eigenvalue }=0.25, \\
\text { Inertia proportion } \\
\text { explained }=0.05\end{array}$} & \multirow{2}{*}{$\begin{array}{c}\text { CCA } \\
\text { Eigenvalue }=0.12, \\
\text { Inertia proportion } \\
\text { explained }=0.04\end{array}$} \\
\hline & $\begin{array}{l}\text { Festucetea } \\
\text { vaginatae } \\
(\mathrm{n}=100)\end{array}$ & $\begin{array}{c}\text { Festuco- } \\
\text { Puccinellietea } \\
(\mathrm{n}=100)\end{array}$ & $\begin{array}{l}\text { Robinietea } \\
(\mathrm{n}=50)\end{array}$ & & & \\
\hline Achillea euxina Klokov & - & $2.03 \pm 0.29$ & $1.18 \pm 0.4$ & 0.78 & 0.30 & 0.76 \\
\hline Aeluropus littoralis (Gouan) Parl. & $0.05 \pm 0.05$ & $0.16 \pm 0.07$ & $2.03 \pm 0.6$ & -0.17 & 1.04 & -0.11 \\
\hline Agropyron dasyanthum Ledeb. & $1.06 \pm 0.37$ & $0.17 \pm 0.10$ & $0.27 \pm 0.17$ & -0.54 & 0.34 & -0.47 \\
\hline Alkanna tinctoria Tausch & - & $0.09 \pm 0.07$ & - & - & - & - \\
\hline Alyssum hirsutum M.Bieb. & $6.25 \pm 0.52$ & $1.25 \pm 0.31$ & $2.31 \pm 0.46$ & -0.84 & -0.18 & -0.74 \\
\hline Anethum graveolens L. & $0.06 \pm 0.05$ & $0.22 \pm 0.14$ & - & 0.19 & 0.12 & 0.42 \\
\hline Apera spica-venti (L.) P.Beauv. & $0.28 \pm 0.10$ & $2.88 \pm 0.49$ & - & 0.56 & -0.07 & 0.42 \\
\hline Artemisia caerulescens L. & $0.92 \pm 0.26$ & $0.44 \pm 0.21$ & $1.92 \pm 0.59$ & -0.37 & 0.31 & -0.14 \\
\hline Asperula setulosa Boiss. & $0.01 \pm 0.01$ & $0.04 \pm 0.04$ & $0.07 \pm 0.07$ & -0.10 & 0.75 & -0.07 \\
\hline Astragalus varius S. G. Gmel. & $1.15 \pm 0.22$ & $0.03 \pm 0.03$ & $0.32 \pm 0.21$ & -1.09 & 0.03 & -1.03 \\
\hline Bromus squarrosus $\mathrm{L}$. & $1.97 \pm 0.41$ & $0.94 \pm 0.22$ & $1.58 \pm 0.47$ & -0.38 & -0.48 & -0.24 \\
\hline B. japonicus Thunb. & $1.36 \pm 0.36$ & $1.53 \pm 0.4$ & $1.79 \pm 0.76$ & -0.06 & 0.03 & -0.10 \\
\hline Calamagrostis epigeios (L.) Roth & - & $2.51 \pm 0.84$ & - & 0.84 & 0.24 & 0.96 \\
\hline Capsella bursa-pastoris (L.) Medik. & - & - & $1.15 \pm 0.38$ & 0.25 & 1.37 & 0.47 \\
\hline Carex colchica J.Gay & $1.88 \pm 0.55$ & - & - & -0.37 & 0.04 & -0.33 \\
\hline C. extensa Gooden. & - & $4.70 \pm 0.65$ & $11.95 \pm 1.85$ & 0.23 & 0.49 & 0.29 \\
\hline Centaurea odessana Prodan & $0.16 \pm 0.09$ & $0.20 \pm 0.14$ & - & -0.32 & 0.72 & -0.33 \\
\hline Chenopodium album $\mathrm{L}$. & - & $0.45 \pm 0.25$ & - & 1.61 & -2.98 & 0.93 \\
\hline Consolida regalis Gray & $0.07 \pm 0.04$ & $0.13 \pm 0.07$ & - & -0.35 & -0.32 & -0.14 \\
\hline Crepis foetida $\mathrm{L}$. & - & - & $0.08 \pm 0.06$ & - & - & - \\
\hline Cynanchum acutum $\mathrm{L}$. & $0.50 \pm 0.17$ & $8.15 \pm 0.79$ & $7.11 \pm 1.61$ & 0.75 & -0.04 & 0.76 \\
\hline Cynodon dactylon (L.) Pers. & $4.89 \pm 0.69$ & $3.74 \pm 0.55$ & $2.01 \pm 0.48$ & -0.37 & 0.04 & -0.33 \\
\hline Diplotaxis muralis (L.) DC. & $0.07 \pm 0.05$ & $0.29 \pm 0.13$ & - & 0.09 & 0.34 & 0.17 \\
\hline Elymus repens (L.) Gould & - & $20.25 \pm 1.21$ & $6.87 \pm 1.35$ & 0.87 & -0.26 & 0.66 \\
\hline Eryngium campestre L. & $0.10 \pm 0.05$ & $0.21 \pm 0.12$ & $0.52 \pm 0.25$ & 0.00 & 1.28 & 0.52 \\
\hline Erysimum diffusum Ehrh. & $0.12 \pm 0.07$ & $1.58 \pm 0.28$ & $4.33 \pm 0.60$ & 0.41 & 0.84 & 0.53 \\
\hline Euphorbia seguieriana Neck. & $10.42 \pm 0.70$ & $0.48 \pm 0.13$ & $6.99 \pm 0.84$ & -0.84 & 0.05 & -0.78 \\
\hline Falcaria vulgaris Bernh & - & $0.23 \pm 0.09$ & $0.84 \pm 0.47$ & 0.31 & 0.92 & 0.40 \\
\hline Festuca valesiaca Schleich. ex Gaudin & - & $1.94 \pm 0.48$ & - & 1.21 & -0.73 & 0.73 \\
\hline Galium aparine $\mathrm{L}$. & $0.3 \pm 0.13$ & $2.71 \pm 0.38$ & $4.18 \pm 0.70$ & 0.56 & 0.43 & 0.74 \\
\hline Gypsophila paniculata $\mathrm{L}$. & $0.01 \pm 0.01$ & $0.2 \pm 0.13$ & - & 0.95 & -0.94 & 0.43 \\
\hline Juncus gerardii Loisel. & $0.68 \pm 0.31$ & $2.95 \pm 0.75$ & $2.09 \pm 0.73$ & 0.36 & 0.62 & 0.40 \\
\hline Lepidium campestre (L.) R.Br. & - & $0.07 \pm 0.05$ & - & - & - & - \\
\hline $\begin{array}{l}\text { Leymus racemosus ssp. sabulosus (M. Bieb.) } \\
\text { Tzvelev }\end{array}$ & $0.02 \pm 0.02$ & $0.29 \pm 0.20$ & - & 0.00 & 0.14 & -0.08 \\
\hline Limonium meyeri (Boiss.) Kuntze & $0.12 \pm 0.09$ & $5.00 \pm 0.53$ & - & 1.03 & -0.80 & 0.76 \\
\hline Marrubium peregrinum $\mathrm{L}$. & $0.76 \pm 0.22$ & $0.06 \pm 0.03$ & $0.08 \pm 0.08$ & -0.89 & -0.23 & -0.68 \\
\hline Medicago falcata $\mathrm{L}$. & $0.26 \pm 0.09$ & $0.93 \pm 0.23$ & $0.02 \pm 0.02$ & 0.24 & -0.14 & 0.36 \\
\hline M. minima (L.) L. & $0.26 \pm 0.11$ & $0.75 \pm 0.29$ & $0.09 \pm 0.09$ & 0.08 & -0.34 & -0.15 \\
\hline M. monspeliaca (L.) Trautv. & $0.34 \pm 0.17$ & $0.25 \pm 0.11$ & - & -0.04 & -0.27 & -0.23 \\
\hline Melilotus albus Medik. & - & $0.24 \pm 0.17$ & - & - & - & - \\
\hline Papaver rhoeas L. & $0.01 \pm 0.01$ & $0.03 \pm 0.02$ & - & 0.13 & 0.52 & 0.12 \\
\hline Phragmites australis (Cav.) Trin. ex Steud. & $0.02 \pm 0.01$ & $1.59 \pm 0.36$ & - & 1.26 & -1.34 & 1.00 \\
\hline Plantago dubia $\mathrm{L}$. & $0.04 \pm 0.04$ & $0.27 \pm 0.10$ & - & 0.58 & 0.06 & 0.40 \\
\hline P. salsa Pall. & $0.01 \pm 0.01$ & $0.01 \pm 0.01$ & $0.03 \pm 0.03$ & - & - & - \\
\hline Poa bulbosa $\mathrm{L}$ & $0.87 \pm 0.36$ & $9.25 \pm 0.95$ & $0.23 \pm 0.16$ & 0.79 & -0.63 & 0.40 \\
\hline Polygonum arenarium Waldst. \& Kit. & - & - & $0.27 \pm 0.17$ & - & - & - \\
\hline Scorzonera ensifolia M.Bieb. & - & $0.05 \pm 0.03$ & - & 1.40 & -1.59 & 1.03 \\
\hline Secale sylvestre Host & $13.95 \pm 1.12$ & $0.76 \pm 0.21$ & $1.69 \pm 0.59$ & -1.07 & -0.25 & -1.03 \\
\hline $\begin{array}{l}\text { Senecio leucanthemifolius subsp. vernalis } \\
\text { (Waldst. \& Kit.) Greuter }\end{array}$ & $0.21 \pm 0.08$ & $3.48 \pm 0.47$ & $4.77 \pm 0.93$ & 0.51 & 0.30 & 0.57 \\
\hline Pleconax subconica Sourkova & $1.27 \pm 0.21$ & $2.60 \pm 0.37$ & $0.90 \pm 0.41$ & -0.05 & -0.22 & -0.14 \\
\hline Sonchus arvensis L. & $0.02 \pm 0.02$ & $0.18 \pm 0.09$ & $0.42 \pm 0.24$ & 0.66 & 1.53 & 0.75 \\
\hline Stellaria holostea L. & $0.22 \pm 0.08$ & $1.49 \pm 0.31$ & $1.54 \pm 0.51$ & 0.40 & 0.43 & 0.41 \\
\hline Stipa pennata L. & $0.89 \pm 0.20$ & $0.01 \pm 0.01$ & $0.07 \pm 0.07$ & -1.22 & -0.96 & -0.92 \\
\hline S. capillata $\mathrm{L}$. & - & $0.17 \pm 0.07$ & $2.58 \pm 0.7$ & 0.45 & 1.80 & 0.98 \\
\hline Teucrium polium $\mathrm{L}$. & $5.69 \pm 0.58$ & $0.07 \pm 0.05$ & $2.23 \pm 0.45$ & -1.01 & -0.15 & -0.94 \\
\hline Thalictrum foetidum $\mathrm{L}$. & - & $0.19 \pm 0.09$ & $0.08 \pm 0.08$ & 0.81 & 0.46 & 0.52 \\
\hline Verbascum pinnatifidum Vahl & $0.01 \pm 0.01$ & - & - & - & - & - \\
\hline Vincetoxicum fuscatum (Hornem.) Rchb. f. & - & $0.46 \pm 0.18$ & $0.86 \pm 0.35$ & 0.42 & 1.28 & 0.55 \\
\hline Viola tricolor $\mathrm{L}$. & $0.06 \pm 0.06$ & - & $0.03 \pm 0.03$ & - & - & - \\
\hline
\end{tabular}

Moisture conditions common to the vegetation class Festucetea vaginatae were preferred by xerophytes. Xerophytes are plants adapted to very dry steppe habitats. The Robinietea vegetation class inhabited humidity conditions that were preferred by sub-xerophytes - plants adapted to meadow-steppe habitats. The moisture regime of the Festuco-Puccinellietea vegetation class was preferred by sub-mesophytes - plants adapted to rather dry forest-meadow habitats. The regime of moisture variability in the vegetation classes Festucetea vaginatae and Robinietea was preferred by the hemi-hydrocontrastophiles. These are plants adapted to the dry meadow-steppe habitats with an irregular moistening of the soil layer. More contrasting conditions of moisture variability were indicated for the class Festuco-Puccinellietea. Such conditions are preferred by the hydrocontrastophiles - plants adapted to the dry steppe or damp habitats forming under an extremely irregular moistening of the soil layer. 
Table 3

Relationship between plant species and the number of fecal pellets of red deer (based on pairwise correlation coefficients, significant at $\mathrm{P}<0.05$; positive relationship $-\uparrow$, negative relationship $-\downarrow$ )

\begin{tabular}{lccc}
\hline \multicolumn{1}{c}{ Species } & $\begin{array}{c}\text { Festucetea } \\
\text { vaginatae }\end{array}$ & $\begin{array}{c}\text { Festuco- } \\
\text { Puccinellietea }\end{array}$ & Robinietea \\
\hline Achillea euxina & - & $\uparrow$ & - \\
Agropyron dasyanthum & $\uparrow$ & - & - \\
Alyssum hirsutum & - & - & $\uparrow$ \\
Apera maritima & $\uparrow$ & - & - \\
Artemisia santonica & $\uparrow$ & - & - \\
Asperula setulosa & - & - & $\uparrow$ \\
Bromis japonicus & $\uparrow$ & - & - \\
Carex extensa & - & - & - \\
Centaurea odessana & - & $\uparrow$ & - \\
Cynanchum acutum & $\uparrow$ & - & - \\
Cynodon dactylon & - & $\uparrow$ & - \\
Diplotaxis muralis & $\uparrow$ & - & - \\
Elymus repens & - & - & $\uparrow$ \\
Erysimum diffusum & - & - & $\downarrow$ \\
Euphorbia seguieriana & $\downarrow$ & - & - \\
Galium aparine & $\uparrow$ & - & - \\
Limonium meyeri & $\uparrow$ & - & - \\
Marrubium peregrinum & - & $\uparrow$ & - \\
Medicago falcata & - & - & $\uparrow$ \\
Secale sylvestre & $\downarrow$ & - & - \\
Teucrium polium & $\downarrow$ & - & - \\
Verbascum pinnatifidum & - & - & $\uparrow$ \\
\hline
\end{tabular}

The acidity of the soils in which the class Festucetea vaginatae inhabited favoured neutrophiles - plants which grow on acidulous and neutral $(\mathrm{pH}=6.5-7.1)$ soils. The soils under Festuco-Puccinellietea and Robinietea were more acidic, which favoured sub-acidophiles - plants which grow on faintly acid $(\mathrm{pH}=5.5-6.5)$ soil of meadow marsh habitats. The trophic regime favoured semi-eutrophes, which prefer soils enriched with salt (150$200 \mathrm{mg} / \mathrm{L}$ ) with a content of $\mathrm{HCO}_{3}^{-} 4-16 \mathrm{mg} / 100 \mathrm{~g}$ of soil, and trace of $\mathrm{SO}_{4}{ }^{2-}$ and $\mathrm{Cl}^{-}$in some types. The soils were nitrogen poor. The vegetation class Festucetea vaginatae was represented mainly by anitrophiles - plants which grow on very poor non-nitrogen dystrophic soils. The Festuco-Puccinellietea and Robinietea classes were represented mainly by sub-anitrophiles - plants which grow on poor on mineral nitrogen oligotrophic soils, where organic residue are decomposed very quickly, their products are washed and content of mineral nitrogen is $5-20 \mathrm{mg} / 100 \mathrm{~g}$ of soil.

The correspondence analysis of the vegetation revealed two ordination axes. The ordination axis 1 (CA1) was able to explain $11.3 \%$ of community inertia, and the ordination axis 2 (CA2) was able to explain $5.2 \%$ of community inertia. CA1 was strongly positively correlated with soil nitrogen content, moisture content, moisture variability, and aeration regime and negatively correlated with acidity, carbonate content, and light regime. The markers of positive CA1 scores were Ch. album, S. ensifolia, $P h$. australis, and $F$. valesiaca. The markers of negative scores on this axis were $T$. polium, $S$. sylvestre, A. varius, and $S$. pennata. CA2 was strongly positively correlated with carbonate content and ombroclimate, and negatively correlated with ecotope trophicity, acidity, and light regime. The markers of positive CA2 scores were S. capillata, S. arvensis, C. bursa-pastoris, $V$. fuscatum, and E. campestre. The markers of negative CA2 scores were $S$. pennata, Ph. australis, S. ensifolia, and Ch. album. The number of deer fecal pellets formed a regular pattern in the space of axes 1 and 2 (Fig. 3). The maximum excretory activity of animals was recorded for the central part of the ordination space, indicating the presence of an optimum zone in the gradient of environmental factors that structure plant communities.

\section{Table 4}

Phytoindication estimates of environmental factors and their correlation with ordinal axes

\begin{tabular}{|c|c|c|c|c|c|c|c|c|}
\hline \multirow{2}{*}{$\begin{array}{l}\text { Indicator } \\
\text { scales }\end{array}$} & \multirow{2}{*}{$\begin{array}{l}\text { Ecological } \\
\text { factors }\end{array}$} & \multicolumn{3}{|c|}{ Vegetation classes } & \multirow{2}{*}{ CA1 } & \multirow{2}{*}{$\mathrm{CA} 2$} & \multirow{2}{*}{$R^{2}$} & \multirow{2}{*}{$p$-level } \\
\hline & & Festucetea vaginatae $(\mathrm{N}=100)$ & Festuco-Puccinellietea $(\mathrm{N}=100)$ & Robinietea $(\mathrm{N}=50)$ & & & & \\
\hline \multirow{12}{*}{ Didukh* } & $\mathrm{Hd}$ & $6.04 \pm 0.18$ & $9.52 \pm 0.24$ & $7.87 \pm 0.32$ & 0.99 & -0.03 & 0.40 & 0.001 \\
\hline & $\mathrm{fH}$ & $7.69 \pm 0.20$ & $10.04 \pm 0.07$ & $8.77 \pm 0.28$ & 0.99 & -0.06 & 0.32 & 0.001 \\
\hline & $\mathrm{Rc}$ & $9.33 \pm 0.09$ & $8.92 \pm 0.10$ & $8.74 \pm 0.15$ & -0.74 & -0.68 & 0.06 & 0.002 \\
\hline & $\mathrm{Sl}$ & $8.55 \pm 0.19$ & $8.64 \pm 0.23$ & $8.06 \pm 0.40$ & 0.07 & -0.99 & 0.05 & 0.002 \\
\hline & $\mathrm{Ca}$ & $8.50 \pm 0.26$ & $7.55 \pm 0.18$ & $7.96 \pm 0.37$ & -0.68 & 0.73 & 0.05 & 0.002 \\
\hline & $\mathrm{Nt}$ & $1.83 \pm 0.08$ & $3.30 \pm 0.16$ & $3.17 \pm 0.22$ & 0.96 & 0.29 & 0.28 & 0.001 \\
\hline & $\mathrm{Ae}$ & $4.67 \pm 0.11$ & $5.48 \pm 0.13$ & $5.01 \pm 0.14$ & 0.92 & -0.38 & 0.19 & 0.001 \\
\hline & $\mathrm{Tm}$ & $9.45 \pm 0.05$ & $10.14 \pm 0.04$ & $9.95 \pm 0.07$ & 0.99 & 0.09 & 0.30 & 0.001 \\
\hline & $\mathrm{Om}$ & $9.65 \pm 0.16$ & $9.81 \pm 0.10$ & $9.99 \pm 0.17$ & 0.43 & 0.90 & 0.02 & 0.099 \\
\hline & $\mathrm{Kn}$ & $13.73 \pm 0.18$ & $10.72 \pm 0.16$ & $11.83 \pm 0.25$ & -0.95 & -0.32 & 0.42 & 0.001 \\
\hline & $\mathrm{Cr}$ & $9.94 \pm 0.08$ & $9.55 \pm 0.06$ & $9.71 \pm 0.12$ & -0.97 & 0.22 & 0.03 & 0.017 \\
\hline & Lc & $8.43 \pm 0.01$ & $8.33 \pm 0.01$ & $8.31 \pm 0.01$ & -0.94 & -0.34 & 0.31 & 0.001 \\
\hline \multirow{6}{*}{ Ellenberg } & light & $6.98 \pm 0.02$ & $6.82 \pm 0.04$ & $6.74 \pm 0.05$ & -0.60 & -0.80 & 0.11 & 0.001 \\
\hline & temperatures & $11.29 \pm 0.06$ & $10.88 \pm 0.06$ & $10.59 \pm 0.09$ & -0.58 & -0.81 & 0.18 & 0.001 \\
\hline & continentality & $12.07 \pm 0.09$ & $10.77 \pm 0.07$ & $10.97 \pm 0.14$ & -0.89 & -0.45 & 0.41 & 0.001 \\
\hline & humidity & $3.43 \pm 0.05$ & $6.30 \pm 0.09$ & $5.76 \pm 0.16$ & 0.97 & 0.24 & 0.75 & 0.001 \\
\hline & acidity & $9.11 \pm 0.07$ & $8.85 \pm 0.06$ & $9.29 \pm 0.11$ & -0.94 & 0.34 & 0.03 & 0.038 \\
\hline & nutrients & $2.93 \pm 0.04$ & $4.60 \pm 0.04$ & $4.34 \pm 0.10$ & 0.97 & 0.23 & 0.82 & 0.001 \\
\hline
\end{tabular}

Note: $\mathrm{Hd}$ - the soil water regime, $\mathrm{fH}$ - the variability of damping, $\mathrm{Ae}$ - the soil aeration, $\mathrm{Rc}$ - the soil acidity, $\mathrm{Sl}$ - the total salt regime, $\mathrm{Ca}$ - the carbonate content in soil, $\mathrm{Nt}$ the nitrogen content in soil, Tm - the thermal climate, $\mathrm{Om}$ - the ombroregime, $\mathrm{Kn}$ - the continentality, $\mathrm{Cr}$-the cryo-climate, $\mathrm{Lc}-$ the light regime.

Within the class Festucetea vaginatae, the Mantel test showed a strong positive correlation between the matrices of sampling point distances represented by measures of red deer excretory activity and nutrient availability (Table 5). A partial correlation including the plant community matrix did not alter this correlation. There was a correlation between the excretory activity matrix and the plant matrix that does not change with the nutrient availability matrix when the partial correlation is calculated. Within the Festuco-Puccinellietea class, the Mantel test revealed a negative correlation between sampling point distance matrices represented by measures of red deer excretory activity and nutrient availability. A partial correlation including the plant community matrix did not alter this correlation. No statistically significant correlation was found between the excretory activity matrix and the plant matrix. Within the Robinietea class, no statistically significant correlations between matrices were found. A canonical correspondence analysis with environmental factors as covariates explained $21.2 \%$ of the variation in the plant community structure $(\mathrm{F}=$ 4.72, $\mathrm{P}<0.001)$. The forward selection procedure allowed the nutrients availability variable to be selected as the most important variable to explain variation in the plant community structure. A canonical correspondence analysis with nutrients availability as a covariate explained $9.2 \%$ of the variation in the plant community structure $(\mathrm{F}=25.11, \mathrm{P}<0.001)$.

Thus, nutrients availability was the most important factor that structures the plant community and can probably be responsible for the variability of excretory activity of ungulates. The number of deer fecal pellets exhibited different patterns of response in the nutrients availability gradient. The response within the plant class Festucetea vaginatae could best be explained by Model III from the list of HOF-models (Fig. 4). This model is a sigmoid curve, which is obviously a fragment of a bell-shaped curve that is truncated because of the limited gradient of nutrients availability within the plant community of the class Festucetea vaginatae. 
The estimates indicate an optimum of excretory activity in the nutrients availability range, which was 3.93-4.50. The response of the excretory activity of deer within the class Festuco-Puccinellietea could best be fitted by the model IV, which represents a symmetric Gaussian curve. The optimum of excretory activity was at the level of 4.86. The response of excretory activity in the Robinietea vegetation class was asymmetrical bimodal with optimums of 3.78 and 5.02 .

\section{Discussion}

We studied the excretory activity of red deer within the vegetation classes that occupy a large part of Biryuchiy Island. Sandy steppes (class Festucetea vaginatae) occupy $28.2 \%$ of the territory on Biryuchiy Island (Kolomiychuk \& Bezkorovajnyj, 2011). The dominant species are C. colchica, C. dactylon, E. seguierana. Steppes are associated with high parts of the spit. F. beckeri and M. peregrinum also dominate on sandyshell soils. A. lavrenkoanum, E. distachya, S. sylvestre, T. polium, C. diffusa, E. minor are co-dominants in sandy steppes. A. guttatum, A. hirsutum, A. maeotica, A. varius, C. uncinatus, L. austriacum, M. falcata. M. capillatae, and M. falcata are less common on the spit (Dubyna et al., 1995; Kolomiychuk \& Bezkorovajnyj, 2011). Saline meadows (class FestucoPuccinellietea) occupy $26.8 \%$ of the island territory. The community of E. elongata and $E$. repens is typical for the flattened or lowered areas of the Spit of Biryuchiy Island. Often E. elongata forms a pure stand, in other places A. maeotica, A. maritima, A. littoralis, C. epigeios, L. latifolium, L. meyeri, Ph. australis form associated with it. The constant components of meadows are L. caspium, C. acutum, A. santonica. A large area is occupied by cenoses dominated by $P$. distans and $P$. brachylepis. A. santonica, $H$. verrucifera, S. perennans, S. maritima, T. pannonicum are the dominant species in these communities. The saline meadow communities are also dominated by A. maritim, A. littoralis and S. holoschoenus (Dubyna et al., 1995; Kolomiychuk \& Bezkorovajnyj, 2011). The forestation on the island was discontinued at the end of the 1990s. A considerable part of deciduous plantations of the forest area, with the exception of monocultures of Elaeagnus angustifolia L., was destroyed due to ungulates after removal of the fence around the forest area. During the 1950s and 1970s. 116 species of trees and shrubs were planted on the island. Only 51 species of trees and shrubs were found on the island in 2009. Some tree and shrub species (Ulmus minor Mill., Ligustrum vulgare L., Prunus spinosa L.) had become creeping due to destruction of apical buds by ungulates (Dubyna et al., 1995; Kolomiychuk \& Bezkorovajnyj, 2011).

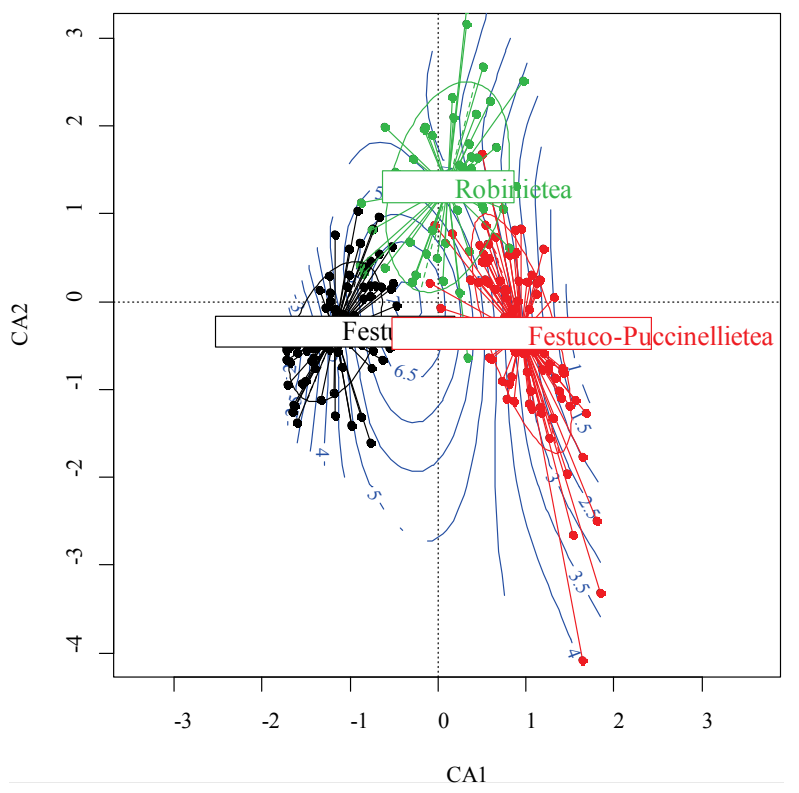

Fig. 3. The location of sampling points in the space of ordination axes 1 and 2: abscissa axis is CA1, ordinate axis is CA2, the red points are sites that belong to the plant class Festucetea vaginatae, the black points are sites that belong to the plant class Festuco-Puccinellietea, the green points are sites that belong to the plant class Robinietea; the blue lines are isolines of quantities of red deer fecal pellets

Table 5

Paired and partial correlation between matrices of sampling point distances expressed in measures of red deer excretory activity, nutrients availability, and plant community structure

\begin{tabular}{|c|c|c|c|c|c|c|c|c|}
\hline \multirow{2}{*}{ Plant class } & \multicolumn{2}{|c|}{ Correlation between matrixes } & \multicolumn{3}{|c|}{ Mantel test } & \multicolumn{3}{|c|}{$p$-value* } \\
\hline & pairwise correlation & partial correlation & $r$ & $2.5 \%$ low limit & 97.5\% upper limit & 1 & 2 & 3 \\
\hline \multirow{4}{*}{ Festucetea vaginatae } & Fecal pellets $\times$ Nutrients availability & - & 0.48 & 0.40 & 0.52 & 0.001 & 1.00 & 0.001 \\
\hline & - & [Plant community] & 0.47 & 0.40 & 0.51 & 0.001 & 1.00 & 0.001 \\
\hline & Fecal pellets $\times$ Plant community & - & 0.31 & 0.27 & 0.36 & 0.001 & 1.00 & 0.001 \\
\hline & - & [Nutrients availability] & 0.30 & 0.26 & 0.34 & 0.001 & 1.00 & 0.001 \\
\hline \multirow{4}{*}{ Festuco-Puccinellietea } & Fecal pellets $\times$ Nutrients availability & - & -0.08 & -0.10 & -0.05 & 0.95 & 0.052 & 0.13 \\
\hline & - & [Plant community] & -0.08 & -0.10 & -0.05 & 0.97 & 0.029 & 0.10 \\
\hline & Fecal pellets $\times$ Plant community & - & 0.02 & -0.04 & 0.08 & 0.30 & 0.70 & 0.68 \\
\hline & - & [Nutrients availability] & 0.03 & -0.04 & 0.10 & 0.29 & 0.71 & 0.62 \\
\hline \multirow{4}{*}{ Robinietea } & Fecal pellets $\times$ Nutrients availability & - & -0.08 & -0.10 & -0.05 & 0.87 & 0.13 & 0.27 \\
\hline & - & [Plant community] & -0.06 & -0.08 & -0.04 & 0.80 & 0.20 & 0.38 \\
\hline & Fecal pellets $\times$ Plant community & - & -0.05 & -0.09 & -0.01 & 0.80 & 0.20 & 0.39 \\
\hline & - & [Nutrients availability] & -0.03 & -0.06 & 0.01 & 0.65 & 0.35 & 0.65 \\
\hline
\end{tabular}

Note: * - P-value 1 - one-tailed p-value (null hypothesis: $\mathrm{r} \leq$ ); $\mathrm{P}$-value 2 - one-tailed p-value (null hypothesis: $\mathrm{r} \geq 0$ ); $\mathrm{P}$-value 3 - two-tailed P-value (null hypothesis: $\mathrm{r}=0$ ).

The distribution of deer fecal pellets in all vegetation classes is such that it can best be fitted by a geometric distribution. The geometric distribution can be used to describe the number of failed attempts before the first success (Forbes et al., 2010). The geometric model is widely used to model vertebrate dispersion. The application of the geometric model is based on the assumption that the habitat is divided into discrete units and that there is a constant probability that the animal will stop when it crosses each of these units (Buechner, 1987). Thus, the geometric distribution of fecal pellets suggests that food objects of deer are not evenly distributed in space. It is also true that the food objects that are located at the correspondding loci are particularly significantly different in their level of preference compared to the surrounding plants. This result is true for the Festuco-Puccinellietea and Robinietea vegetation classes. For the vegetation class Festucetea vaginatae, a stable tendency of deviation from the geometrical law of distribution was observed. The level of plant species preference variation for the vegetation class Festucetea vaginatae can be assumed to be significantly lower than for the other vegetation classes. It can also be assumed that the level of vegetation mosaicism is lower for the vegetation class Festucetea vaginatae than for the other vegetation classes. In other words, the assumptions on which the geometric distribution is based are not fully fulfilled for the vegetation class Festucetea vaginatae. It should be noted that the beta diversity is higher for the plant class Festucetea vaginatae than for the other two. Therefore, the most probable explanation for the deviation of the experimental distribution of deer fecal pellets from the geometrical law may be the level of spatial mosaicism of the vegetation cover.

The population density of red deer on the island until the end of the XX century ranged from $9.1-10.8 \mathrm{ind} . \mathrm{km}^{2}$. At the beginning of the XXI century, the population density of this species increased, but stabilized at the level of 13.9-20.8 ind./.m² (Domnich, 2015). Earlier density estimates 
were obtained for the island as a whole. Accounting for fecal pellets made it possible to elucidate the biotopic features of red deer distribution. Such characteristics as excretory intensity and pellet decomposition rate are also important for solving this problem. The estimates of the decomposition rate were obtained based on the dynamics of weight loss by red deer feces. This estimate was 1,371 days for steppe ecosystems; 1,026 days for grassland ecosystems; and 1,200 days for an artificial forest plantation. In studies by other scientists, estimates of the rate of decomposition of feces have different values. Decay rate estimates are 581 days (Alves et al., 2013). In one extreme case, samples taken in July completely disappeared within 95 days. For samples taken in November, it took about 450 days for complete decay (Mitchell \& McCowan, 1984). The use of logistic regression to estimate the probability of decay as a function of time yielded estimates of 252-295 days (Laing et al., 2003). There is a risk with using the relationship between fecal pellet counts and deer density to estimate deer densities in areas other than those where this relationship has been found (Forsyth, 2005). This is mainly due to differences in pellet deposition and decomposition, which ultimately affects the number of pellets (Cochran \&
Stains, 1961). Differences in the quality and quantity of food in different habitats generally affect the rate of pellet deposition (Rogers et al., 1958), while the rate of pellet decomposition depends on changes in rainfall (Nugent et al., 1997). Retention of pellets was lowest in wet forest and highest in dry, open areas (Harestad \& Bunnell, 1987). Because of fluctuations in forage abundance combined with varying precipitation levels, pellet count studies should be conducted in the same area and at the same time of year (Nugent et al., 1997). Thus, we can explain the long period of red deer fecal decomposition in the conditions of Biryuchiy Island by the significant aridity of the climate. The estimates of this index, which are much smaller, were obtained in more humid climatic conditions. It should be noted that within Biryuchiy Island there is a significant variability in humidity conditions, which also affects the rate of fecal decomposition. This circumstance should be taken into account when estimating the red deer population density. The obtained estimates of red deer population density by biotopes agree well with the estimates of this indicator for the island as a whole. This result indicates that the fecal pellet technique can be applied to finding out the biotopic preferences of red deer.
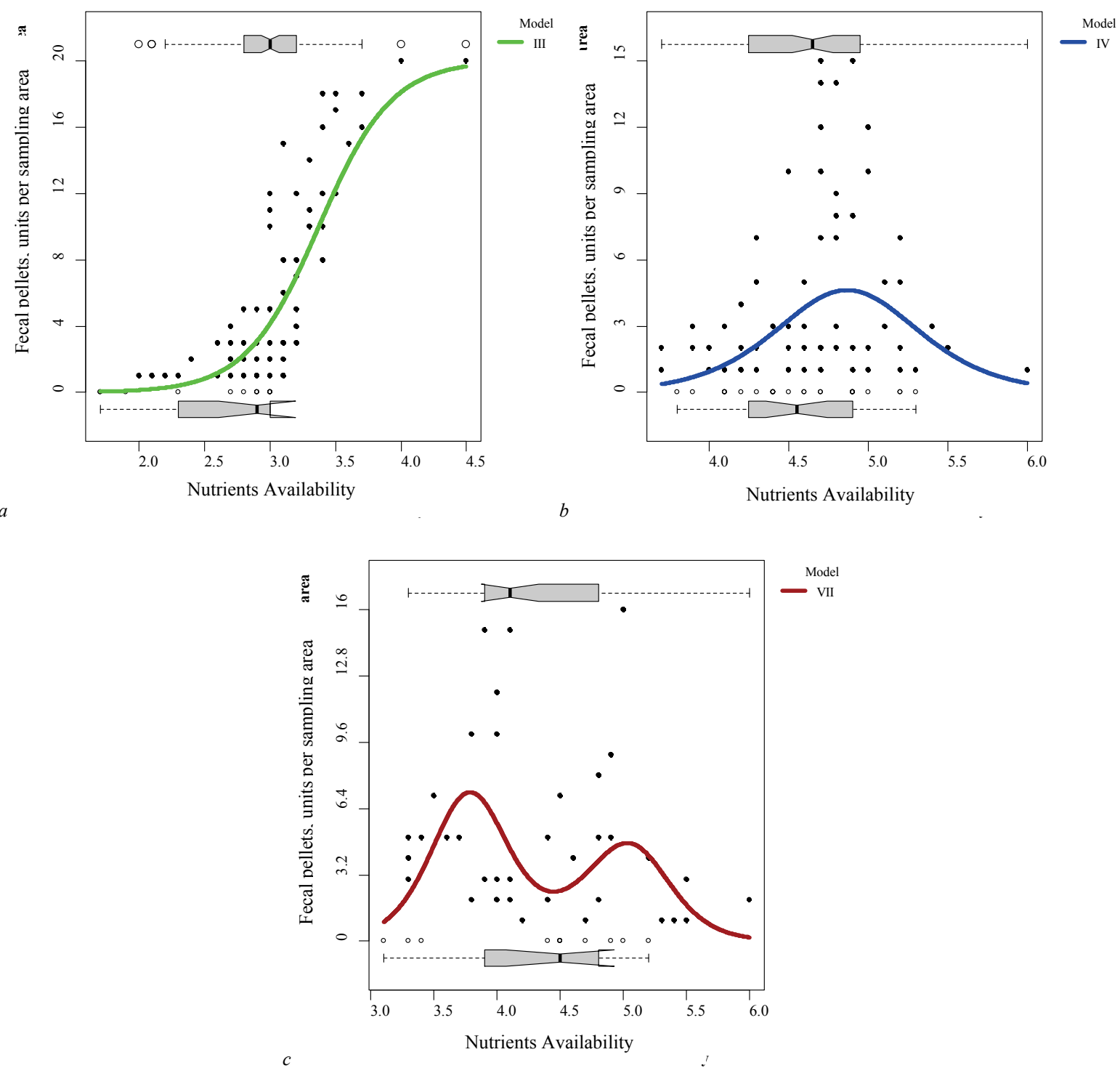

Fig. 4. Models of the response of red deer fecal pellets in the nutrients availability gradient in different vegetation classes:

$a$-Festucetea vaginatae; $b$-Festuco-Puccinellietea; $c$-Robinietea; abscissa axis is phytoindicating nutrients availability estimates; ordinate axis is fecal pellets, units per sampling area; model III from the list of HOF-models is optimal for the vegetation class Festucetea vaginatae: top value is 19.6, optmin= 3.93 , optmax $=4.50$, central border low is 3.47 , central border high is 4.50 , outer border low is 2.85 , outer border high is 4.50 ; optimal model IV from the

list of HOF-models is optimal for the vegetation class Festuco-Puccinellietea: opt $=4.86$, central border low is 4.42, central border high is 5.31, outer border low is 3.86, outer border high is 5.86; for vegetation class Robinietea optimal is model VII from the list of HOF-models: opt1 $=3.78$, opt2 $=5.02$, central border low 1 is 3.48 , central border high 1 is 4.11 , central border low 2 is 4.63 , central border high 2 is 5.35 , outer border low1 is 3.11 , outer border high1 is 4.46 ; outer border low 2 is 4.44 , outer border high 2 is 5.64 
Deer have a negative effect on litter thickness, which is consistent with the results of other studies. Thus, it was found that the litter mass in the zone of high deer density was significantly lower. The soil is significantly compacted as a result of deer exposure, soil $\mathrm{pH}$ decreased by 2.18 units. Also organic carbon content decreases under the impact of deer (Kumbasli et al., 2010). Browsing by red deer is known to negatively affect the availability of nitrogen in the soil (Harrison, 2004).

The phytoindication assessment of environmental factors has advantages in comparison with instrumental methods of the measurement of environmental properties (Zverev, 2020). Plants represent an integrated expression of environmental variables that can fluctuate greatly in time and space and that cannot be estimated by single measurements. The measurements depend on the technical equipment and can often be more timeconsuming and financially expensive than a simple floristic observation. In the absence of old measurements, the bioindicators are indispensable; they make it possible to estimate the extent of environmental change (Zonneveld, 1983). The plant communities integrate the variability of environmental characteristics and reflect the most significant ecological regimes (Szymura et al., 2014; Bartelheimer \& Poschlod, 2016). The phytoindication assessments are not sensitive to temporary catastrophic events, but show the most important trends (Didukh, 2011). Rather, phytoindication indicates not the quantitative value of the environmental factor, but the relations of the plant community to this factor. This is also another advantage, since plants are the most important mediators between animals, especially herbivores, and the ecological environment. It should also be noted that, with a certain degree of conditionality, phytoindication estimates can be converted into absolute physical units, which quantitatively characterize environmental factors (Didukh, 2011). Habitat assessments based on the phytoindication method are used to quantitatively characterize the ecological niche of animals (Zimaroeva et al., 2016; Yorkina et al., 2018; Zhukov et al., 2019; Ponomarenko et al., 2021).

The results we obtained indicate that the variability of the plant community is due to the effects of various environmental factors. Among them, the most significant are the gradient of nitrogen nutrient content and the gradient of salinity. These gradients have a complex character. Thus, the gradient of nitrogen nutrient content is a conjugate variability of other ecological properties, such as moisture, moisture variability, lightness, and some others. In general, this gradient contrasts the relatively poor ecotopes of Festucetea vaginatae with the relatively rich ecotopes of Festuco-Puccinellietea. Robinietea ecotopes occupy an intermediate position in this gradient. It should be pointed out that this gradient repeats the relief features of the island. More elevated positions are occupied by Festucetea vaginatae, and lower positions are occupied by Festuco-Puccinellietea. The salinity gradient is inversely related to the soil carbonate content and also correlates with the climatic regimes, especially those reflecting the temperature features of the ecotope. This gradient contrasts forested Robinietea ecosystems with non-forested meadow and steppe ecosystems. It should be pointed out that the salinity gradient is not a significant driver that affects deer life activity. The gradient of nutrient nitrogen content is of leading importance. It should be mentioned that the red deer are known as an intermediate feeder (Hofmann, 1989). This species feeds mainly on concentrated food year-round, and only one-third of its diet consists of grasses and sedges. Concentrated foods are easy to digest, rich in available contents of plant cells such as leaves of trees and shrubs, grasses, seeds and fruits (Gonzalez-Hernandez \& Silva-Pando, 1999). The proportion of different types of concentrated food varies depending on the habitat, but not on the season (with the exception of seeds and fruits) (Gebert \& Verheyden-Tixier, 2008). The species composition of deer fecal pellets was dominated by graminoids with dwarf shrubs as an important secondary component, and other grasses were represented in minor proportions. The spatial homogeneity of the fecal composition did not reflect significant differences in meadow vegetation between different territories because deer locally selected nutritious graminoids (especially fescue Festu$c a$ ) at the patch level (Suter et al., 2004).

Obviously, the importance of the nitrogen gradient is due to the fact that even small changes in plant quality have a significant impact on animal fitness, as ruminants not only obtain more protein and energy, but also spend less time digesting high-quality forage. Thus, increased access to highly nutritious forage is considered an important driving force in the evolution of migration in large herbivores because the temporal and spatial variation in plant quality is huge. The spatial heterogeneity of relief affects the phenology of plants, actually increasing the period of availability of high-quality forage (Mysterud et al., 2001).

The pattern of the fecal number response in the nitrogen nutrient gradient varies by plant class. For the plant class Festuco-Puccinellietea, the response is Gaussian bell-shaped with traditionally symmetrical shape (Austin, 2002; Oksanen \& Minchin, 2002). When nitrogen compounds in the soil are deficient, the response of the number of fecal pellets in the gradient of this factor is sigmoidal. At very low levels of nitrogen supply, some increase in this factor is not significantly reflected in the number of fecal pellets of deer. When some critical level is reached, even a slight increase in nitrogen in the soil has a positive effect on the number of deer fecal pellets. Such a critical point is "low outer border" which is 2.85 for the equal plant community Festucetea vaginatae. In the plant community Festuco-Puccinellietea equals 3.86, and in the plant community Robinietea equals 3.11. If these phytoindication estimates are converted into physical units, it turns out that up to the level of $0.05-0.10 \%$ of nitrogen in the soil, the number of fecal matter in the soil is not sensitive to changes in its content. In turn, the optimal value of nitrogen content in the soil is $0.16 \%$. An increase in nitrogen content above the optimum level results in a negative effect on the number of faeces of the deer. It can be assumed that an increase in soil nitrogen content leads to an increase in the phytomass of plant communities. The larger plants may be less suitable for digestion, even with high nutritional value. The research of other scientists suggested that the herbivores were able to optimize the energy production by selecting areas with an intermediate biomass of vegetation. The digestible energy content of grasses decreased with increasing biomass due to the change in fiber and lignin content during maturation. Deer energy gain was limited by both the grass biomass and fiber content, with the latter varying inversely with the grass biomass. A behavioural preference for grass patches with intermediate biomass and fiber content explains the patterns of deer aggregation and seasonal migration (Wilmshurst et al., 1995).

An important question is to establish what actually affects the excretory activity of red deer: the gradient of environmental conditions or the features of the vegetation structure. It should be taken into account that the solution to this problem is complicated by the fact that we indexed environmental conditions with the help of scales, which are calculated on the basis of the properties of plant communities. It can be assumed that deer are selective in their choice of forage and this choice is entirely determined by the species features of plants. It can also be assumed that deer do not prefer individual plant species, but some groups of plants that differ from the others by the sum of their properties. Such group properties may be the result of adaptation of plant species to certain ecological regimes. Apparently, this problem is reminiscent of the chicken or the egg causality dilemma: "which came first: the chicken or the egg?" This problem is compounded by another important circumstance. Deer themselves are a source of nitrogen enrichment in the soil. Therefore, the regular spatial patterns of deer can be the reason for the preferential development of the nitrophilic plant species, from which the association of accumulations of deer fecal pellets and certain plant species can arise.

The Mantel test produces results that are consistent with findings from both the ordination procedure and the gradient analysis. For the vegetation class Festucetea vaginatae, a close relationship between deer excretory activity and soil nutrient availability was confirmed. It should be noted that excretory activity also correlates with the plant community matrix. This indicates an important role of exactly the species aspect of the community structure in the variation of the excretory activity of deer. However, it is important that the consideration of the community structure in the calculation of the partial correlation does not affect the correlation of excretory activity and soil nutrient content. This suggests a direct effect of soil trophicity on variation in the excretory activity of deer in the vegetation class Festucetea vaginatae. In the vegetation class Festuco-Puccinellietea, the result is almost the same except that the sign of the correlation of excretory activity and available nutrients is opposite. For this vegetation, the soil trophicity plays an important role, and the species composition of the plant community does not play a role. The bimodal response of fecal number in the soil trophicity gradient in the Robinietea vegetation class is consistent with the absence of statistically significant correlation between 
matrices based on the results of the Mantel test. There may be several reasons for this. The accuracy of phytoindication of ecological regimes in an artificial forest plantation may be much lower than in natural ecosystems. The question of the possibility of applying phytoindication to artificial ecosystems has been practically not raised. Anthropogenic dynamics may be a more significant factor that affects the plant community than environmental factors, which may be the cause of the reduced information value of this approach. Also, in the conditions of a forest plantation, the reasons for the selection of microhabitats may be substantially different from the trophic preferences of deer. And it is the trophic factor that is the most likely reason why soil nitrogen content is a driver of the spatial variation in the deer excretory activity across the study area as a whole. The protective properties of the forest plantation can significantly regulate the preferences in the spatial location of animals. The information that the need to find shelter can cause deer to select habitats with poorer forage quality confirms our assumptions (Staines, 2009; Pérez-Barbería et al., 2013).

The decreasing importance of the species composition of plant communities in the variation of the excretory activity of red deer in the series Festucetea vaginatae $\rightarrow$ Festuco-Puccinellietea $\rightarrow$ Robinietea is confirmed by data on the pairwise correlation of the number of deer fecal pellets with the projective cover of individual plant species. The number of statistically significant correlations also decreases in the above series. In addition, it should be noted that among the statistically significant correlations there is a relationship with plant species that are not forage ones. Such species among the flora of Biryuchy Island include $A$. santonica, M. peregrinum, which also correlate with the number of deer fecal pellets. Obviously, the reason for this correlation is not directly trophic in nature. It can be assumed that these species respond to the trophicity of the ecosystem. If the ecotope has sufficient trophicity, the conditions are created for the growth of other plants which are of forage value for deer.

The range of ecological conditions within Biryuchiy Island is much wider than was considered in the present study. Therefore, the ecological properties of the red deer ecological niche in both the drier and less mineralized part of the range of ecological conditions and the wetter and more mineralized part should be assessed in the context of the prospects for future studies. To translate the information obtained by counting fecal pellets into an index of animal abundance, additional studies of the rate of fecal decomposition in a wider range of environmental conditions are needed. Also of interest is the interpreting of remote sensing data from terrestrial vegetation records and the application of vegetation indices as ecogeographic predictors of the ecological niche of red deer.

\section{Conclusion}

The phytoindication assessment of environmental factors allows us to explain the variation in red deer abundance. The nutrient content of the soil is an important gradient that structures the plant community and influences deer abundance. The nature of the response of red deer abundance to the available nutrient gradient varies between plant classes. In steppe communities (class Festucetea vaginatae) the response is sigmoidal, in saline meadows (class Festuco-Puccinellietea) the response is symmetrical bell-shaped, and in artificial forest plantations (class Robinietea) the response is asymmetrical bimodal. The role of environmental factors greatly exceeds the importance of the relationship of deer to individual plant species.

The authors declare that there is no conflict of interest between them.

\section{References}

Acevedo, P., \& Cassinello, J. (2009). Human-induced range expansion of wild ungulates causes niche overlap between previously allopatric species: Red deer and Iberian ibex in mountainous regions of Southern Spain. Annales Zoologici Fennici, 46(1), 39-50.

Alves, J., Alves da Silva, A., Soares, A. M. V. M., \& Fonseca, C. (2013). Pellet group count methods to estimate red deer densities: Precision, potential accuracy and efficiency. Mammalian Biology, 78(2), 134-141.

Austin, M. P. (2002). Spatial prediction of species distribution: An interface between ecological theory and statistical modelling. Ecological Modelling, 157, 101-118.
Bagherirad, E., Abdullah, M., \& Amirkhani, M. (2013). Using pellet group counts to estimate the population size of the Persian gazelle in the steppe area of Golestan National Park, Iran. Malaysian Applied Biology, 42(2), 51-57.

Ball, M. E. (1974). Floristic changes on grasslands and heaths on the Isle of Rhum after a reduction or exclusion of grazing. Journal of Environmental Management, 2, 299-318.

Barrios-Garcia, M. N., \& Ballari, S. A. (2012). Impact of wild boar (Sus scrofa) in its introduced and native range: A review. Biological Invasions, 14(11), 2283-2300.

Bartelheimer, M., \& Poschlod, P. (2016). Functional characterizations of Ellenberg indicator values - a review on ecophysiological determinants. Functional Ecology, 30(4), 506-516.

Bennett, L. J., English, P. F., \& McCain, R. (1940). A study of deer populations by use of pellet-group counts. The Journal of Wildlife Management, 4(4), 398.

Bobrowski, M., Gillich, B., \& Stolter, C. (2015). Modelling browsing of deer on beech and birch in Northern Germany. Forest Ecology and Management, 358, 212-221.

Bodmer, R. E. (1990). Ungulate frugivores and the browser-grazer continuum. Oikos, 57(3), 319 .

Braun-Blanquet, J. (1964). Pflanzensoziologie, Grundzüge der Vegetationskunde. 3rd ed. Springer Vienna, Vienna.

Britton, A., \& Pakeman, R. (2009). Vegetation monitoring of Rum Natura habitats. Scottish Natural Heritage Commissioned Report, F05LC06, 1-90.

Buechner, M. (1987). A geometric model of vertebrate dispersal: Tests and implications. Ecology, 68(2), 310-318.

Chytry, M., Tichy, L., Drevojan, P., Sádlo, J., \& Zeleny, D. (2018). Ellenberg-type indicator values for the Czech flora. Preslia, 90(2), 83-103.

Cochran, G. A., \& Stains, H. J. (1961). Deposition and decomposition of fecal pellets by Cottontails. The Journal of Wildlife Management, 25(4), 432.

Côté, S. D., Rooney, T. P., Tremblay, J.-P., Dussault, C., \& Waller, D. M. (2004). Ecological impacts of deer overabundance. Annual Review of Ecology, Evolution, and Systematics, 35(1), 113-147.

Debeljak, M., Džeroski, S., Jerina, K., Kobler, A., \& Adamič, M. (2001). Habitat suitability modelling for red deer (Cervus elaphus L.) in South-Central Slovenia with classification trees. Ecological Modelling, 138, 321-330.

Didukh, Y. P. (2011). The ecological scales for the species of Ukrainian flora and their use in synphytoindication. Phytosociocenter, Kyiv.

Domnich, A. V. (2015). Ratychni yak strukturno-funktsionalnyi element ostrivnykh zapovidno-okhoronnykh terytorii Pivdennoho Skhodu Ukrainy [Ungulates as a structural-functional element of island and steppe ecosystems in conservation areas of south-east of Ukraine]. Dnipro National University Press, Dnipro (in Ukranian).

Dubyna, D. V., Neuhäuslová, Z., \& Shelyag-Sosonco, J. R. (1994). Coastal vegetation of the "Birjucij Island" Spit in the Azov Sea, Ukraine. Preslia, 66, 193-216.

Dubyna, D. V., Neuhäuslová, Z., \& Shelyag-Sosonco, J. R. (1995). Vegetation of the "Birjucij Island" Spit in the Azov Sea. Sand steppe vegetation. Folia Geobotanica and Phytotaxonomica, 3(1), 1-31.

Dufresne, M., Bradley, R. L., Tremblay, J.-P., Poulin, M., \& Pellerin, S. (2009). Clearcutting and deer browsing intensity interact in controlling nitrification rates in forest floor. Écoscience, 16(3), 361-368.

Eberhardt, L., \& Van Etten, R. C. (1956). Evaluation of the pellet group count as a deer census method. The Journal of Wildlife Management, 20(1), 70.

Ellenberg, H., Weber, H. E., Dull, R., Wirth, V., Werner, W., \& Paulissen, D. (1991). Zeigerwerte von Pflanzen in Mitteleuropa. Scripta Geobotanica, 18, 1-248.

Feest, A., Van Swaay, C., \& Van Hinsberg, A. (2014). Nitrogen deposition and the reduction of butterfly biodiversity quality in the Netherlands. Ecological Indicators, 39, 115-119.

Forsyth, D. M. (2005). Protocol for estimating changes in the relative abundance of deer in New Zealand forests using the Faecal Pellet Index (FPI). Landcare Research contract report LC0506/027 to the Department of Conservation, Lincoln, New Zealand.

Gebert, C., \& Verheyden-Tixier, H. (2008). Variations of diet composition of Red deer (Cervus elaphus L.) in Europe. Mammal Review, 31, 189-201.

Gonzalez-Hernandez, M. P., \& Silva-Pando, F. J. (1999). Nutritional attributes of understory plants known as components of deer diets. Journal of Range Management, 52(2), 132.

Goslee, S. C., \& Urban, D. L. (2007). The ecodist package for dissimilarity-based analysis of ecological data. Journal of Statistical Software, 22(7), 1-19.

Hanley, T. A. (1997). A nutritional view of understanding and complexity in the problem of diet selection by deer (Cervidae). Oikos, 79(2), 209.

Harestad, A. S., \& Bunnell, F. L. (1987). Persistence of black-tailed deer fecal pellets in coastal habitats. The Journal of Wildlife Management, 51(1), 33.

Harrison, K. (2004). Browsing by red deer negatively impacts on soil nitrogen availability in regenerating native forest. Soil Biology and Biochemistry, 36(1), 115-126.

Heckel, C. D., Bourg, N. A., McShea, W. J., \& Kalisz, S. (2010). Nonconsumptive effects of a generalist ungulate herbivore drive decline of unpalatable forest herbs. Ecology, 91(2), 319-326. 
Heinken, T., \& Raudnitschka, D. (2002). Do wild ungulates contribute to the dispersal of vascular plants in central European forests by epizoochory? A case study in NE Germany. Forstwissenschaftliches Centralblatt, 121(4), 179-194.

Hierl, L. A., Franklin, J., Deutschman, D. H., Regan, H. M., \& Johnson, B. S. (2008). Assessing and prioritizing ecological communities for monitoring in a regional habitat conservation plan. Environmental Management, 42(1), 165-179.

Hirzel, A. H., \& Le Lay, G. (2008). Habitat suitability modelling and niche theory. Journal of Applied Ecology, 45(5), 1372-1381.

Hirzel, A. H., Hausser, J., Chessel, D., \& Perrin, N. (2002). Ecological-niche factor analysis: How to compute habitat-suitability maps without absence data? Ecology, 83(7), 2027-2036.

Hobbs, N. T. (1996). Modification of ecosystems by ungulates. The Journal of Wildlife Management, 60(4), 695.

Hofmann, R. R. (1989). Evolutionary steps of ecophysiological adaptation and diversification of ruminants: A comparative view of their digestive system. Oecologia, 78(4), 443-457.

Holmes, S. A., \& Webster, C. R. (2011). Herbivore-induced expansion of generalist species as a driver of homogenization in post-disturbance plant communities. Plant Ecology, 212(5), 753-768.

Horsák, M., Hájek, M., Tichý, L., \& Juřičková, L. (2007). Plant indicator values as a tool for land mollusc autecology assessment. Acta Oecologica, 32(2), 161-171.

Huisman, J., Olff, H., \& Fresco, L. F. M. (1993). A hierarchical set of models for species response analysis. Journal of Vegetation Science, 4(1), 37-46.

Jansen, F., \& Oksanen, J. (2013). How to model species responses along ecologica gradients - Huisman-Olff-Fresco models revisited. Journal of Vegetation Science, 24(6), 1108-1117.

Kappes, H., Kopeć, D., \& Sulikowska-Drozd, A. (2014). Influence of habitat structure and conditions in floodplain forests on mollusc assemblages. Polish Journal of Ecology, 62(4), 739-750.

Kay, R. N. B., \& Staines, B. W. (1981). The nutrition of the Red deer (Cervus elaphus). Nutrition Abstracts and Reviews, Series B, 51, 601-622.

Knapp, A. K., Blair, J. M., Briggs, J. M., Collins, S. L., Hartnett, D. C., Johnson, L. C., \& Towne, G. (1999). The keystone role of bison in North American tallgrass prairie. BioScience, 49, 39-50.

Knight, T. M., Dunn, J. L., Smith, L. A., Davis, J., \& Kalisz, S. (2009). Deer facilitate invasive plant success in a Pennsylvania forest understory. Natural Areas Journal, 29(2), 110-116.

Kolomiychuk, V. P., \& Bezkorovajnyj, O. S. (2011). Vegetation dynamics of Biryuchy Island Spit (Kherson region). Gruntoznavstvo, 12, 95-100.

Konvicka, M., Hula, V., \& Fric, Z. (2003). Habitat of pre-hibernating larvae of the endangered butterfly Euphydryas aurinia (Lepidoptera: Nymphalidae): What can be learned from vegetation composition and architecture? European Journal of Entomology, 100(3), 313-322.

Kuijper, D. P. J. (2011). Lack of natural control mechanisms increases wildlife-forestry conflict in managed temperate European forest systems. European Journal of Forest Research, 130(6), 895-909.

Kuijper, Dries P.J., Jędrzejewska, B., Brzeziecki, B., Churski, M., Jędrzejewski, W., \& Żybura, H. (2010). Fluctuating ungulate density shapes tree recruitment in natural stands of the Białowieża Primeval Forest, Poland. Journal of Vegetation Science, 21(6), 1082-1098

Kumbasli, M., Makineci, E., \& Cakir, M. (2010). Long-term effects of Red deer (Cervus elaphus) grazing on soil in a breeding area. Journal of Environmenta Biology, 31, 185-188.

Kunakh, O. N., Kramarenko, S. S., Zhukov, A. V., Zadorozhnaya, G. A., \& Kramarenko, A. S. (2018). Intra-population spatial structure of the land snail Vallonia pulchella (Müller, 1774) (Gastropoda; Pulmonata; Valloniidae). Ruthenica 28(3), 91-99.

Laing, S. E., Buckland, S. T., Burn, R. W., Lambie, D., \& Amphlett, A. (2003) Dung and nest surveys: Estimating decay rates. Journal of Applied Ecology, 40(6), 1102-1111.

Long, Z. T., Pendergast, T. H., \& Carson, W. P. (2007). The impact of deer on relationships between tree growth and mortality in an old-growth beech-maple forest. Forest Ecology and Management, 252, 230-238.

Massé, A., \& Côté, S. D. (2012). Linking habitat heterogeneity to space use by large herbivores at multiple scales: From habitat mosaics to forest canopy openings. Forest Ecology and Management, 285, 67-76.

Melis, C., Buset, A., Aarrestad, P. A., Hanssen, O., Meisingset, E. L., Andersen, R. Moksnes, A., \& Røskaft, E. (2006). Impact of red deer Cervus elaphus grazing on bilberry Vaccinium myrtillus and composition of ground beetle (Coleoptera, Carabidae) assemblage. Biodiversity and Conservation, 15(6), 2049-2059.

Mirzoeva, A., \& Zhukov, O. (2021). Conchological variability of Anadara kagoshimensis (Bivalvia: Arcidae) in the northern part of the Black-Azov Sea basin. Biologia.

Mitchell, B., \& McCowan, D. (1984). The defecation frequencies of Red deer in different habitats. In: Institute of Terrestrial Ecology. Annual Report 1983. Henry Ling Limited, The Dorset Press, Dorchester, Dorset. Pp. 15-17.
Moore, E. K., Britton, A. J., Iason, G., Pemberton, J., \& Pakeman, R. J. (2015). Landscape-scale vegetation patterns influence small-scale grazing impacts. Biological Conservation, 192, 218-225.

Müller, A., Dahm, M., Bøcher, P. K., Root-Bernstein, M., \& Svenning, J.-C. (2017). Large herbivores in novel ecosystems - Habitat selection by Red deer (Cervus elaphus) in a former brown-coal mining area. PLoS One, 12(5), e0177431.

Mysterud, A., Langvatn, R., Yoccoz, N. G., \& Stenseth, N. C. (2001). Plant phenollogy, migration and geographical variation in body weight of a large herbivore: The effect of a variable topography. Journal of Animal Ecology, 70(6), 915-923.

Nugent, G., Fraser, K. W., \& Sweetapple, P. J. (1997). Comparison of Red deer and possum diets and impacts in podocarp-hardwood forests, Waihaha catchment, Pureora Conservation Park. Science for Conservation, 50. Dept. of Conservation, Wellington.

Nuttle, T. Ristau, T. E \& Royo, A A (2014). Long-term biological legacies of herbivore density in a landscape-scale experiment: Forest understoreys reflect past deer density treatments for at least 20 years. Journal of Ecology, 102(1), 221-228.

Oksanen, J., \& Minchin, P. R. (2002). Continuum theory revisited: What shape are species responses along ecological gradients? Ecological Modelling, 157, 119-129.

Oostermeijer, J. G. B., \& van Swaay, C. A. M. (1998). The relationship between butterflies and environmental indicator values: A tool for conservation in a changing landscape. Biological Conservation, 86(3), 271-280.

Pendergast, T. H., Hanlon, S. M., Long, Z. M., Royo, A. A., \& Carson, W. P. (2016) The legacy of deer overabundance: Long-term delays in herbaceous understory recovery. Canadian Journal of Forest Research, 46(3), 362-369.

Pérez-Barbería, F. J., Hooper, R. J., \& Gordon, I. J. (2013). Long-term density-dependent changes in habitat selection in Red deer (Cervus elaphus). Oecologia 173(3), 837-847.

Pielech, R., Zając, K., Kadej, M., Malicki, M., Malkiewicz, A., \& Tarnawski, D. (2017). Ellenberg's indicator values support prediction of suitable habitat for pre-diapause larvae of endangered butterfly Euphydryas aurinia. PLoS One, 12(6), e0179026.

Ponomarenko, O., Banik, M., \& Zhukov, O. (2021). Assessing habitat suitability for the Common Pochard, Aythya ferina (Anseriformes, Anatidae) at different spatial scales in Orel' River valley, Ukraine. Ekológia (Bratislava), 40(2), 154-162.

Prokudin, Y. N. (Ed.). (1987). Opredelitel' vysshykh rastenij Ukrainy [Identification key to higher plants of Ukraine]. Naukova Dumka, Kyiv (in Russian).

Rogers, G., Julander, O., \& Robinette, W. L. (1958). Pellet-group counts for deer census and range-use index. The Journal of Wildlife Management, 22(2), 193.

Rooney, T. P., \& Waller, D. M. (2003). Direct and indirect effects of white-tailed deer in forest ecosystems. Forest Ecology and Management, 181, 165-176.

Sabo, A. E., Frerker, K. L., Waller, D. M., \& Kruger, E. L. (2017). Deer-mediated changes in environment compound the direct impacts of herbivory on understorey plant communities. Journal of Ecology, 105(5), 1386-1398.

Semiadil, G., Barry, T. N., Muir, P. D., \& Hodgson, J. (1995). Dietary preferences of sambar (Cervus unicolor) and red deer (Cervus elaphus) offered browse, forage legume and grass species. The Journal of Agricultural Science, 125(1), 99-107.

Sokal, R. R., \& Rohlf, F. J. (1995). Biometry: The principles and practice of statistics in biological research. W. H. Freeman and Co., New York

Sokolov, S. G. \& Zhukov, A. V. (2017). Functional diversity of a parasite assemblages of the Chinese sleeper Perccottus glenii Dybowski, 1877 (Actinopterygii: Odontobutidae) and habitat structure of the host. Biology Bulletin, 44(3), 331-336.

Staines, B. W. (2009). The use of natural shelter by Red deer (Cervus elaphus) in relation to weather in North-East Scotland. Journal of Zoology, 180(1), 1-8.

Suter, W., Suter, U., Kriisi, B., \& Schütz, M. (2004). Spatial variation of summer diet of red deer Cervus elaphus in the Eastern Swiss Alps. Wildlife Biology, 10(1), $43-50$.

Szymura, T. H., Szymura, M., \& Macioł, A. (2014). Bioindication with Ellenberg's indicator values: A comparison with measured parameters in Central European oak forests. Ecological Indicators, 46, 495-503.

Tahtinen, B., Murray, B. D., Webster, C. R., Tarasoff, C. S., \& Burton, A. J. (2014) Does ungulate foraging behavior in forest canopy gaps produce a spatial subsidy with cascading effects on vegetation? Forest Science, 60(5), 819-829.

Ter Braak, C. J. F. (1986). Canonical correspondence analysis: A new eigenvector technique for multivariate direct gradient analysis. Ecology, 67(5), 1167-1179.

Tiitsaar, A., Kaasik, A., Lindman, L., Stanevitš, T., \& Tammaru, T. (2016). Host associations of Coenonympha hero (Lepidoptera: Nymphalidae) in Northern Europe: Microhabitat rather than plant species. Journal of Insect Conservation, 20(2), 265-275.

Tschöpe, O., Wallschläger, D., Burkart, M., \& Tielbörger, K. (2011). Managing open habitats by wild ungulate browsing and grazing: A case-study in NorthEastern Germany. Applied Vegetation Science, 14(2), 200-209.

Waller, D. M., \& Alverson, W. S. (1997). The white-tailed deer: A keystone herbivore. Wildlife Society Bulletin, 25, 217-226.

Webster, C. R., Jenkins, M. A., \& Rock, J. H. (2005). Long-term response of spring flora to chronic herbivory and deer exclusion in Great Smoky Mountains National Park, USA. Biological Conservation, 125(3), 297-307. 
Williams, C. D., Moran, J., Doherty, O., Mc Donnell, R. J., Gormally, M. J., Knutson, L. V., \& Vala, J.-C. (2009). Factors affecting Sciomyzidae (Diptera) across a transect at Skealoghan Turlough (Co. Mayo, Ireland). Aquatic Ecology, 43(1), $117-133$.

Wilmshurst, J. F., Fryxell, J. M., \& Hudsonb, R. J. (1995). Forage quality and patch choice by wapiti (Cervus elaphus). Behavioral Ecology, 6(2), 209-217.

Yorkina, N., Maslikova, K., Kunah, O., \& Zhukov, O. (2018). Analysis of the spatial organization of Vallonia pulchella (Muller, 1774) ecological niche in technosols (Nikopol Manganese Ore Basin, Ukraine). Ecologica Montenegrina, 17(1), 29-45.

Zhukov, O., Kunah, O., Dubinina, Y., \& Novikova, V. (2018). The role of edaphic, vegetational and spatial factors in structuring soil animal communities in a floodplain forest of the Dnipro River. Folia Oecologica, 45, 8-23.

Zhukov, O., Kunah, O., Dubinina, Y., Zhukova, Y., \& Ganzha, D. (2019). The effect of soil on spatial variation of the herbaceous layer modulated by overstorey in an Eastem European poplar-willow forest. Ekologia (Bratislava), 38(3), 253-272.
Zhukov, O., Kunah, O., Fedushko, M., Babchenko, A., \& Umerova, A. (2021). Temporal aspect of the terrestrial invertebrate response to moisture dynamic in technosols formed after reclamation at a post-mining site in Ukrainian steppe drylands. Ekológia (Bratislava), 40(2), 178-188.

Zimaroeva, A. A., Zhukov, O. V., \& Ponomarenko, O. L. (2016). Determining spatial parameters of the ecological niche of Parus major (Passeriformes, Paridae) on the base of remote sensing data. Vestnik Zoologii, 50(3), 251-258.

Zonneveld, I. S. (1983). Principles of bio-indication. Environmental Monitoring and Assessment, 3, 207-217.

Zverev, A. A. (2020). Methodological aspects of using indicator values in biodiversity analysis. Contemporary Problems of Ecology, 13(4), 321-332.

Zymaroieva, A., Zhukov, O., Fedoniuk, T., Pinkina, T., \& Hurelia, V. (2021). The relationship between landscape diversity and crops productivity: Landscape scale study. Journal of Landscape Ecology, 14(1), 39-58. 